\title{
1 Petrologic monitoring at Volcán de Fuego, Guatemala
}

2 Emma J. Liu ${ }^{1 *}$, Katharine V. Cashman ${ }^{2}$, Ellen Miller ${ }^{3}$, Hannah Moore ${ }^{2,4}$, Marie Edmonds ${ }^{3}$,

3 Barbara E. Kunz ${ }^{5}$, Frances Jenner ${ }^{5}$, Gustavo Chigna ${ }^{6}$

$4 \quad{ }^{1}$ Department of Earth Sciences, University College London, Gower Place, London, UK (*emma.liu@ucl.ac.uk)

$5 \quad{ }^{2}$ School of Earth Sciences, University of Bristol, Wills Memorial Building, Bristol, U.K.

$6{ }^{3}$ Department of Earth Sciences, University of Cambridge, Downing Street, Cambridge, U.K.

$7 \quad{ }^{4}$ Department of Earth Sciences, University of Tasmania, AUS

$8 \quad{ }^{5}$ School of Environment, Earth \& Ecosystem Sciences, Open University, Milton Keynes, UK

$9 \quad{ }^{6}$ Instituto Nacional de Sismología, Vulcanología, Meteorología e Hidrología, Guatemala, Guatemala City

\section{ABSTRACT}

Paroxysmal activity represents an end-member in the common range of activity at mafic arc volcanoes, characterised by rapid transitions across the effusive-explosive interface and thus posing significant challenges to hazard assessment. Conceptual models to explain changes in the frequency and magnitude of these paroxysmal events are based either on magma recharge or an increase in gas flux, largely framed in the context of two-phase flow. Gas- and magmadriven models are both viable mechanisms to explain the varying styles of paroxysmal behaviour observed in mafic systems; however, each has different implications for future activity. We present time series petrologic data for ash and lava samples collected at Volcán de Fuego, Guatemala, during paroxysmal eruptions between 2011 and 2018. We show that a stepchange in glass composition occurred between 2015 and 2016, reflecting an increase in magma temperature and a reduction in pre-eruptive crystallisation, concurrent with an escalation in the frequency of paroxysmal activity. There was no change in the bulk or phase compositions during this period. To explain these observations, we propose that the increase in frequency of paroxysmal eruptions is modulated by the supply of exsolved volatiles from lower crustal 
27 degassing magmas, without invoking repeated transfer of new, primitive magma to a shallow reservoir. Protracted lava effusion, accompanied by more vigorous and more frequent Strombolian explosions and gas 'chugging', prior to the transition to sustained fountaining suggests that gas retention in crystal-rich magma may modulate the height of the magma column as gas supply increases.

Slow decompression associated with effusion may determine the timing of effusive to explosive transitions in mafic arc systems more generally. A large paroxysmal eruption of Fuego on 3 June 2018, notable for the rapid escalation in eruptive intensity several hours into the eruption, produced ash with a range of textures and glass compositions consistent with magma evacuation over a range of depths and decompression rates. Given the protracted repose time between paroxysms before this event, we suggest that a shallow crystallised plug degraded, and ultimately failed, several hours into the eruption of 3 June 2018, triggering topdown decompression of magma in the conduit synchronous with the observed rapid acceleration in eruption rate. Ultimately, we propose that the frequency of paroxysms at Fuego is broadly proportional to the gas supply rate, whilst the range in glass compositions is related to the repose time prior to eruptive activity. Our data illustrate the potential of petrologic monitoring to distinguish between gas- and magma-driven paroxysm triggers and to anticipate future events, especially when interpreted in the context of geophysical observations and implemented within community-based ash collection initiatives.

Keywords: Fuego; paroxysm; citizen science; petrologic monitoring

\section{INTRODUCTION}

Many mafic arc volcanoes exhibit open system behaviour that includes frequent transitions in eruptive activity. The processes that control these transitions, however, have received less 
attention than those that occur in intermediate to silicic magmas (e.g., Cassidy et al., 2018; Sparks et al., 1977; Williamson et al., 2010), although rapid shifts from quiescent to explosive activity at mafic volcanoes pose real challenges for hazard assessment. For example, rapid onset of violent paroxysms at Stromboli volcano (Italy) in July and August 2019 caused one fatality and could have had more severe impacts if the timing of the event had been different, while the frequency of recent ash-producing eruptions at Etna volcano (Italy) poses substantial problems for air traffic. The most destructive paroxysmal eruption of a mafic arc volcano over the past few years, however, was the 3 June 2018 eruption of Volcán de Fuego, Guatemala, where pyroclastic flows and lahars caused $\sim 150$ confirmed fatalities with a further 250 individuals unaccounted for (World Bank, 2019).

Current knowledge of paroxysmal activity derives largely from decades of investigations of Stromboli and Etna volcanoes. At the former, eruptions are dominated by the eponymous Strombolian activity, with occasional lava flows and paroxysms. Here it is well established that normal Strombolian activity is fed from a relatively shallow magma reservoir, while paroxysms tap magma from a separate, deeper reservoir (Bertagnini et al., 2003; Métrich et al., 2010, 2005). Sudden onset paroxysms have been explained by either increased magma flux, causing precursory lava effusion that empties (and decompresses) the upper conduit (Calvari et al., 2011; Ripepe et al., 2017, 2015), or fast ascent of $\mathrm{CO}_{2}$-rich magma (Allard, 2010). Etna volcano, in contrast, has a complex magma storage network that produces eruptions of varying intensity, frequency and vent location (e.g., Andronico et al., 2005; Gambino et al., 2016; Giacomoni et al., 2018; Pompilio et al., 2017). The diversity of paroxysmal activity has given rise to different models of eruptive triggers and processes, although again the conceptual models are based on either magma recharge or an increase in gas flux (e.g., Andronico and Corsaro, 2011; Viccaro et al., 2014), together with varying degrees of pre-eruptive magma storage and degassing (D'Aleo et al., 2019; Spilliaert et al., 2006). 
Important for understanding patterns of activity during persistent or intermittent eruptive episodes is frequent sampling of pyroclastic (e.g., Andronico et al., 2005; Andronico and Corsaro, 2011; Cashman and Hoblitt, 2004; Samaniego et al., 2011; Wright et al., 2012) and/or effusive (e.g., Cashman and McConnell, 2005; Cashman and Taggart, 1983; Corsaro et al., 2013, 2007; Corsaro and Miraglia, 2005; Helz et al., 2014) material. Studies of timeconstrained sample suites have been used in hindsight to characterize changes in eruption style, eruptive mechanisms and locations of pre-eruptive magma storage. Only relatively recently, however, has near-real-time collection and analysis of erupted samples been used in conjunction with more traditional monitoring techniques to track changes in eruption conditions (e.g., Bernard, 2013; Gaunt et al., 2016; Miwa et al., 2013; Miwa and Toramaru, 2013; Taddeucci et al., 2002) or, during the 2018 eruption of Kilauea volcano, to anticipate changes in eruption conditions (Gansecki et al., 2019). The use of petrologic analysis as a monitoring tool requires (1) frequent and systematic sample collection and (2) facilities for rapid analysis. Advances in systematic collection of volcanic ash samples have come from recruitment of citizen scientists (e.g., (Stevenson et al., 2015; Wallace et al., 2015, 2010) and development of low cost and easily assembled ash collectors (Bernard, 2013).

Here we use time-constrained ash samples from eruptive activity at Volcán de Fuego, Guatemala, collected by both volcanologists and citizen scientists over the period of 20112018 to constrain the processes that drive persistent activity at this mafic arc volcano. We show that changes in the matrix glass composition of ash particles correlate with the frequency of explosive paroxysms and the intensity (and volume) of individual eruptions. At the same time, the constant bulk and phase compositions of the erupted material strongly suggest a gas-driven mechanism for paroxysmal activity. 


\section{BACKGROUND}

101

102

103

104

105

106

107

108

109

110

111

112

113

114

115

116

117

118

119

120

121

122

123

124

\subsection{Eruptive activity at Fuego}

Volcán de Fuego, hereafter referred to as Fuego, is an active composite stratovolcano within the Central American volcanic arc (Fig. 1a; Chesner and Rose, 1984). Recent eruptive products include high aluminium basalt to basaltic andesite. Fuego is one of the most persistently active volcanoes in Central America, with $\sim 60,000$ people at risk in surrounding communities (Naismith et al., 2019). Eruption intensity varies over several orders of magnitude (Lyons et al., 2010; Nadeau et al., 2011; Waite et al., 2013) and includes (a) lava flows, (b) minor ash explosions, (c) major explosions (paroxysms) causing widespread (>10 km) ashfall and occasionally airport closure, and (d) sustained sub-Plinian eruptions posing an immediate danger to life and long-term agricultural damage. There have been at least 60 historical subPlinian (VEI 4) eruptions, with the most recent occurring in October 1974 (Rose et al., 2008, 1978).

A 25-year pause in paroxysmal events followed the 1974 eruption before explosive activity resumed in 1999. Since 1999, paroxysms have been erratic, including years with multiple events followed by years with none. Persistent activity was first closely observed by Lyons et al. (2010), who documented repeatable patterns in eruptive activity from 2005-2007. Cycles of activity began with lava effusion and Strombolian eruptions and then progressed to 1-2 days of paroxysmal activity that produced sustained eruption columns, long lava flows and often block-and-ash flows (BAFs); paroxysmal activity was followed by discrete degassing events. During the time period of observation, the frequency and intensity of paroxysms increased while the average lava output rate dropped. This inverse relation between ash and lava emission was also observed during the 1943-1952 eruption of Parícutin, Mexico, where the ratio of tephra to lava increased with eruption rate (Pioli et al., 2009). 
Paroxysmal activity ceased temporarily after 2007, although small background explosions continued through the intervening period accompanied by subdued lava extrusion. Effusion rates escalated again in early 2011. Renewed strong explosive activity recommenced in 2012 with a large eruption on 13 September (Escobar-Wolf, 2013; Fig. 1b). Following several years of sporadic explosive activity, the frequency of paroxysms increased markedly through 2015, after which the repeatable sequence resumed of lava flows from the summit followed by an increasing frequency of explosions and, ultimately, an intense eruptive phase lasting $24-48 \mathrm{hr}$ (Naismith et al., 2019). This pattern was broken on 3 June 2018 when an exceptionally large paroxysm (the largest since 2012) occurred after 5 months of relative quiescence and notably, with a very rapid escalation in eruptive intensity. Highly fluid lava flows began late in the evening on 2 June 2018 and transitioned quickly to lava fountaining from $\sim 04: 30$ (local time) on 3 June. The eruption rate accelerated abruptly at $\sim 12: 00$, generating a tall eruption column and voluminous pyroclastic flows down Barranca Ceniza and Las Lajas (Fig. 1a). Eruptive activity has continued since, but the rate of paroxysmal eruptions has dropped.

The escalation in paroxysm frequency during 2015 was accompanied by a concurrent increase in the number of published volcanic ash advisories, warning of ash at aircraft altitudes (Washington Volcanic Ash Advisory Centre; Fig. 1b). Although the magnitude of the increase may be due, at least in part, to a reporting bias (Naismith et al., 2019), the advisories attest to the generation of energetic eruption columns causing severe disruption to aviation traffic. Local communities regularly report ash fall associated with paroxysmal activity (Table A1; Global Volcanism Program, 2016, 2017). During Strombolian explosions, deposition of measurable quantities of material is generally confined to the proximal edifice, although light ash fall occurs more broadly. 


\subsection{Suggested models for paroxysmal eruptions at Fuego}

152

The origin of paroxysmal eruptions at Fuego has been addressed in several studies. Conceptual models for paroxysms can be defined by the two end members of driven by gas or driven by magma recharge. The argument for gas-driven paroxysms is motivated by observations of paroxysm initiation by gas 'chugging' followed by continuous loud explosions (Lyons et al., 2010). Hypotheses for gas as the primary driving force invoke two-phase flow models (bubbles and melt), including both the collapsing foam model of Vergniolle and Jaupart (1986) and the rise speed dependent model of Parfitt and Wilson (1995).

Magma-driven paroxysms can be recognised by changes in either the bulk composition of erupted magma or in the rim compositions of major crystal phases (e.g., Viccaro et al., 2014). At Fuego, both petrologic data and ${ }^{210} \mathrm{~Pb}$ disequilibrium are consistent with magma recharge prior to the VEI 4 eruption in 1974 (Berlo et al., 2012). There is no evidence, to our knowledge, for further recharge between 1974 and recommencement of paroxysmal activity in 1999; the magma compositions erupted in 1999-2003 are related geochemically to those of the 1974 eruption and are more differentiated (Berlo et al., 2012). Although constraints on pre-1999 ground deformation are lacking, satellite InSAR observations between 2007 and 2010 show slow to negligible rates of edifice deformation $\left(<5 \mathrm{~cm} \mathrm{yr}^{-1}\right)$ suggesting that the volume of any magma intrusion was sufficiently small and/or deep to be below the detection limit of satellite remote sensing (Ebmeier et al., 2013), although certain intrusion geometries and the high compressibility of bubble-rich magmas may dampen any deformation signal (e.g. McCormick Kilbride et al., 2016). An increase in thermal emissions accompanying times of elevated activity in 2003, 2007 and 2015-2018 (Fig. 1b), however, does suggest an increase in height of magma in the conduit (Naismith et al., 2019), as does the lava effusion that precedes most 

paroxysms at Stromboli (Calvari et al., 2011; Ripepe et al., 2015), where the interpretation is that unloading of the magma column by extrusion from flank vents may act as a trigger. Although precursory effusion at Fuego occurs at the summit rather than from flank vents, a similar unloading mechanism involving shedding of material from the summit cone has been suggested by Naismith et al. (2019). They note, however, that this mechanism does not explain all observed events, notably those not preceded by construction of an ephemeral cone in the summit crater-exceptions include the large 2018 eruption.
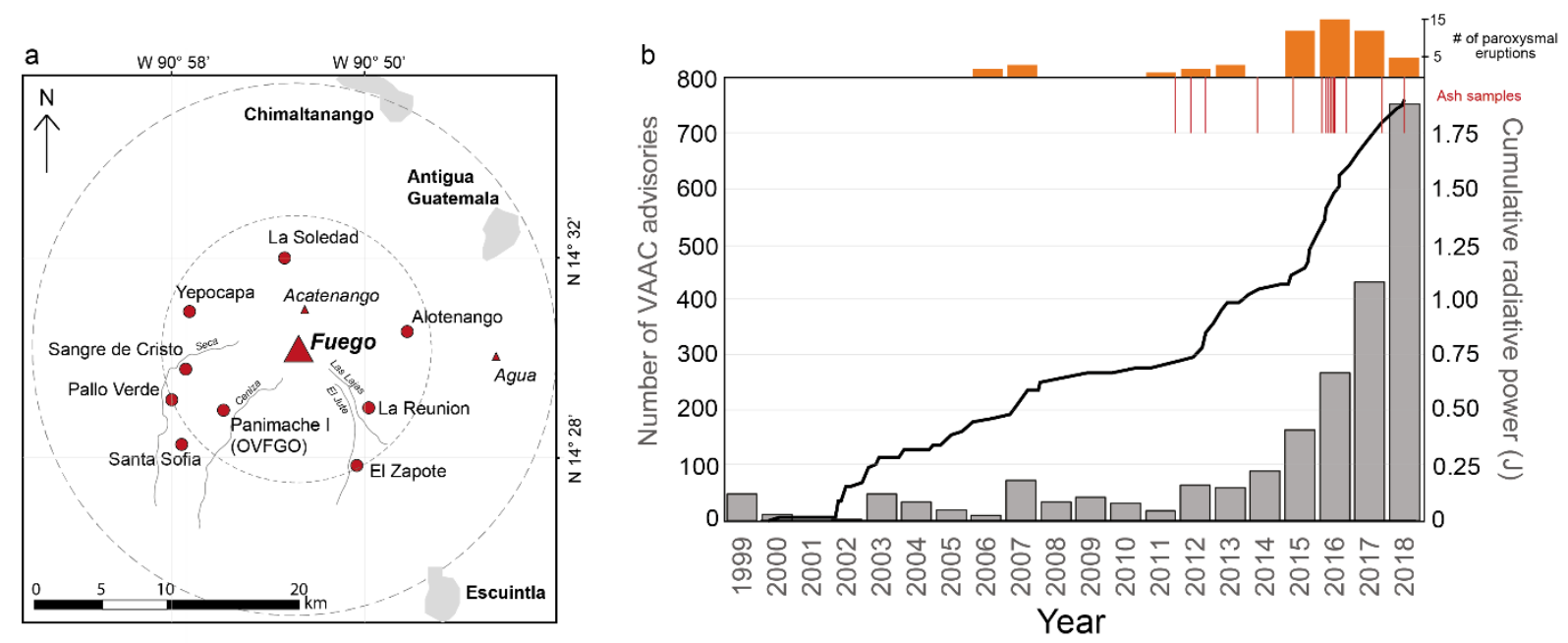

184

Figure 1: Long-term changes in eruptive behaviour; (a) Sampling locations (red circles) relative to local population centres and barrancas (italic), detailed in Table 1; (b) Summary of eruptive activity 1999-2018, showing concurrent increases in cumulative radiative power as measured by a satellite-based thermal (IR) sensor (MODerate resolution Imaging Spectroradiometer, MODIS; data from Naismith et al., 2019), annual number of paroxysmal eruptions (orange bars; INSIVUMEH bulletin reports), and the annual number of volcanic ash advisories indicating ash at aircraft altitudes (grey bars; www.ssd.noaa.gov/VAAC). 


\section{METHODS}

Ash erupted between 2015 and 2017 was collected using low-cost 'ash meters' made from recycled materials (e.g., Bernard, 2013, Fig. A1, supplementary material). The ash meters were installed in nine locations around Fuego, arranged concentrically at distances between 5 and $10 \mathrm{~km}$ from the summit (Fig. 1a, Table 1). Citizen observers maintained the ash meters and collected regular samples following paroxysmal activity. The ash meter timeseries was supplemented with archived ash samples from the Instituto Nacional de Sismología, Vulcanología, Meteorología e Hidrología (INSIVUMEH) — to extend the dataset back to 2011 — and scoria lapilli from the 1974 eruption sampled from Panimache (Fig. 1a; Table A1). Following the 3 June 2018 eruption, additional scoria lapilli samples were collected from rooftops in Antigua shortly after deposition. Lava was sampled from BAF deposits in Barranca Santa Theresa (Seca) and Ceniza in 2017 and Barranca Las Lajas in 2018 (Fig. 1a; Table A1).

Ash samples and crushed scoria lapilli (1974 and 2018) were prepared as polished, carboncoated grain mounts. Lava samples were prepared as thin sections. Backscattered electron (BSE) images of individual ash size fractions were acquired at $15 \mathrm{kV}$ and a $10 \mathrm{~mm}$ working distance using a Quanta650F Field Emission Gun scanning electron microscope (SEM) at the University of Cambridge, UK. We performed image analysis of plagioclase microlite shapes by measuring the axial ratio in ImageJ (Schneider et al., 2012) from binary thresholded BSESEM images with a resolution of 18 pixels $/ \mu \mathrm{m}$, sufficient to resolve microlites. The axial ratio (AxlR) of each crystal is calculated as the ratio of the minor to major axes of the best fit ellipsoid and can take values from 0 to 1 (Liu et al., 2015). Using BSE-SEM image mosaics, we classified the particle assemblage in selected size fractions into components, based on morphology, vesicularity and crystal texture; full descriptions and examples images of each 
component class are reported in Appendix 1 and Figure A.2, respectively (supplementary

217 information).

Major elements and volatiles ( $\mathrm{S}$ and $\mathrm{Cl}$ ) in matrix glasses and mineral phases (olivine, pyroxene and plagioclase) were measured by electron microprobe in both ash and lava samples across three analytical sessions. Geochemical analyses were made on the $250-500 \mu \mathrm{m}$ ash size fraction - the largest fraction that was common to all samples - and therefore our mineral analyses exclude larger phenocrysts. Crystals were also not orientated optimally relative to their crystallographic axes. Operating conditions are described in Appendix 1 (Supplementary Information). Mineral and glass standards were used for calibration. Repeat analyses of secondary standards were monitored throughout each analytical session. To account for small offsets between instruments or between sessions, we normalised major element data using an element-specific correction factor that was determined by comparing secondary standards to published reference values. Within each session, secondary standards showed no instrumental drift. Core-to-rim profiles through olivine were measured with a point spacing of $10 \mu \mathrm{m}$.

We explored the relationships between ash samples using cluster analysis, a multivariate method that assigns 'objects' to groups (also referred to as clades or clusters) based on the similarity of those objects as described by a set of measured continuous variables. No prior assumptions regarding the underlying distribution are required. Here, each ash sample comprises an 'object' described by the major element composition of the matrix glass. All values were normalised to their z-score (i.e., expressed as the number of standard deviations from the mean of the variable) prior to clustering to prevent the more abundant major elements from dominating the analysis; z-scores were then used to calculate the Euclidean distance between samples (i.e., the geometric distance between two objects in multi-dimensional space). We applied an agglomerative clustering algorithm, such that the most related variables are grouped first followed by a progressive reduction in the number of clusters at each hierarchical 
241 level from $n$ clusters of size 1, to one cluster incorporating all samples (i.e., a tree structure).

242 Specifically, we used the Ward method of minimum variance, which creates clusters at each

243 step to minimise the increase in the error sum of the squares (Ward, 1963).

244 We analysed the bulk rock major element composition of selected ash samples (using sample

245 splits made prior to sieving) spanning the sampling interval (Table A1). Rock powders were

246 heated to obtain loss on ignition and subsequently fused with lithium borate flux for major

247 element determination by X-ray fluorescence (XRF) at the University of Leicester, UK.

\begin{tabular}{|c|c|c|c|c|c|}
\hline $\begin{array}{l}\text { Ash } \\
\text { meter } \\
\text { number }\end{array}$ & Location & Latitude & Longitude & $\begin{array}{l}\text { Distance } \\
\text { from the } \\
\text { vent }(\mathbf{k m})\end{array}$ & $\begin{array}{l}\text { Orientation } \\
\text { from the } \\
\text { vent ( } \\
\text { from north) }\end{array}$ \\
\hline 1 & $\begin{array}{l}\text { OVFGO, } \\
\text { Panimache }\end{array}$ & $14^{\circ} 25^{\prime} 56.27^{\prime \prime} \mathrm{N}$ & $90^{\circ} 56^{\prime} 9.55^{\prime \prime W}$ & 7.6 & 232 \\
\hline 2 & Santa Sofia & $14^{\circ} 24^{\prime} 33.45^{\prime \prime} \mathrm{N}$ & $90^{\circ} 58^{\prime} 0.311^{\prime W}$ & 11.8 & 232 \\
\hline 3 & $\begin{array}{l}\text { Finca Palo } \\
\text { Verde }\end{array}$ & $14^{\circ} 26^{\prime} 17.75^{\prime \prime} \mathrm{N}$ & $90^{\circ} 58^{\prime} 24.95 " \mathrm{~W}$ & 10.8 & 249 \\
\hline 4 & Yepocapa & $14^{\circ} 30^{\prime} 2.06^{\prime \prime} \mathrm{N}$ & $90^{\circ} 57^{\prime} 27.21 " \mathrm{~W}$ & 8.8 & 289 \\
\hline 5 & La Soledad & $14^{\circ} 32^{\prime} 10.48^{\prime \prime} \mathrm{N}$ & $90^{\circ} 53^{\prime} 10.76 " \mathrm{~W}$ & 6.7 & 355 \\
\hline 6 & $\begin{array}{l}\text { Sangre de } \\
\text { Cristo }\end{array}$ & $14^{\circ} 27^{\prime} 44.82^{\prime \prime} \mathrm{N}$ & $90^{\circ} 57^{\prime} 40.57^{\prime \prime W}$ & 8.8 & 262 \\
\hline 7 & Alotenango & $14^{\circ} 28^{\prime} 58.87^{\prime \prime} \mathrm{N}$ & $90^{\circ} 48^{\prime} 19.13^{\prime \prime W}$ & 8.2 & 83 \\
\hline 8 & La Reunion & $14^{\circ} 26^{\prime} 15.17 " \mathrm{~N}$ & $90^{\circ} 49^{\prime} 57.76 " \mathrm{~W}$ & 6.6 & 128 \\
\hline 9 & El Rodeo & $14^{\circ} 23^{\prime} 35.84^{\prime \prime} \mathrm{N}$ & $90^{\circ} 50^{\prime} 16.73^{\prime \prime W}$ & 10 & 153 \\
\hline
\end{tabular}

250 Table 1: Locations of the ash meter sampling sites shown in Figure 1a. OVFGO refers to

251 Observatorio del Volcán de Fuego. Details of the ash samples collected are given in Table A1, 252 supplementary materials. 
Ash particles exhibit a crystal-rich (tachylite) texture with a mineral assemblage of plagioclase $(\mathrm{pl})+$ olivine $(\mathrm{ol})+$ clinopyroxene $(\mathrm{cpx})+$ orthopyroxene $(\mathrm{opx})+$ magnetite $(\mathrm{mt})$ within in a silicate glass matrix (gl). Rare amphibole as inclusions in plagioclase has been reported from 1974 samples (Rose et al., 1978), but is absent from the phase assemblage in more recent products since 2011. Olivine is usually the dominant phase within multi-phase glomerocrysts; individual olivine phenocrysts are rare. Plagioclase is ubiquitous as a phenocryst phase, and displays a wide range of compositions and textures as seen in other mafic arc volcanoes (Landi et al., 2004; Viccaro et al., 2014, 2010). Most plagioclase phenocrysts are normally-zoned, with variably resorbed and/or sieve-textured cores (Fig. A.2). Modal core compositions, expressed as An mol\%, are more primitive (An90-95) than the corresponding rims $\left(\mathrm{An}_{65-70}\right)$ in core-rim pairs. The range of core compositions from 2011 to 2016 overlap with those measured from 1974 samples; rims from 1974 are significantly more primitive, however (Fig. A.2). Plagioclase microlites generally have an identical composition to the outer rims of larger phenocrysts, indicating coeval growth.

Bulk rock compositions for the 2011-2018 ash samples (Table A.2, supplementary materials, and Figure 2) are basaltic to basaltic andesite and vary over a relatively small range of $\mathrm{SiO}_{2}$ from 53.5 to $56.0 \mathrm{wt} \%$ (mean $54.4 \pm 1.8[2 \sigma] \mathrm{wt} \%$ ), $\mathrm{MgO}$ from 2.6 to $3.6 \mathrm{wt} \%$ (mean $3.2 \pm$ $0.8[2 \sigma]$ wt $\%$ ) and $\mathrm{K}_{2} \mathrm{O}$ from 0.82 to 1.29 (mean $1.02 \pm 0.33[2 \sigma]$ wt $\%$ ). There is no appreciable evolution in bulk rock chemistry through time, or between pyroclastic (scoria lapilli) and lava samples from 3 June 2018.

To ensure as far as possible that any relative changes in bulk composition during the sampling interval are not due to secondary (transport) fractionation of fragmented particles, we selected samples collected at the same distance from the vent $(7.6-8.8 \mathrm{~km}$; or $\sim 20 \mathrm{~km}$ for 3 June 2018). Although we have no lava equivalent to compare to for most dates, the close similarity between the bulk compositions of lava and tephra for the 3 June 2018 eruption offers some confidence 
that transport processes have not fractionated the tephra substantially. We present detailed component analysis of the particle assemblage in the supplementary material (Table A.3). Within a single size fraction $(250-500 \mu \mathrm{m})$ common to all samples, juvenile particles comprise between $67 \%$ and $86 \%$ of each sample by number; free crystals (either intact or fragments) comprise between $11 \%$ and $26 \%$ (Fig. A.2, supplementary materials). The two exceptions are 08/11/2011 (49 \% juvenile) and 22/05/2016 (38\% juvenile), which both contain notably higher proportions of free crystals: 34 and $52 \%$ respectively. Interestingly, the anomalous assemblages of these two samples are not reflected in their bulk compositions, which are close to the average of all samples; instead it is possible that these samples were not sufficiently mixed during resin mount preparation. Holocrystalline grains, representing either recycled ash grains or eroded fragments of the conduit wall, are a minor component in all samples, generally $<10 \%$ by number, and so do not impart bias to the measured bulk compositions.

Olivine compositions are similar from 2011 through 2018 (Fig. 2). Expressed as forsterite content (Fo mol \%), compositions form a bimodal distribution with a narrow primary mode at Fo68-70 and a broad secondary mode at Fo60-64. Core-to-rim profiles for glomerocryst-hosted olivines show stable core compositions with a steep compositional gradient at crystal margins from Fo68-70 to Fo58-64 (Fig. A.3, supplementary information). Olivine rim compositions during 2011-2015 are slightly more evolved (Fo58-60), although the sample size for this time period is small. In contrast, the olivine populations erupted in 1974 and 1999-2003 are more primitive and described by broad unimodal distributions centred on F074-76 and Fo72-74, respectively (Fig. 2f). Olivine compositions from 2011-2018 overlap with, and extend slightly above, the range of Fo contents predicted to be in equilibrium with the Mg\# of the host glass (Fig. 2b), assuming a K $\mathrm{D}_{\mathrm{D}}$ of 0.27 (Matzen et al., 2011) to 0.35 (Roeder and Emslie, 1970). Under closer scrutiny, it is the secondary (rim) mode (Fo58 - Fo64) that is close to theoretical equilibrium, whilst the primary (core) mode (Fo68-70) is more forsteritic than predicted thermodynamically for the host 
glass composition (see also Fig. A.3). Olivine compositions from 1974 uniformly plot well
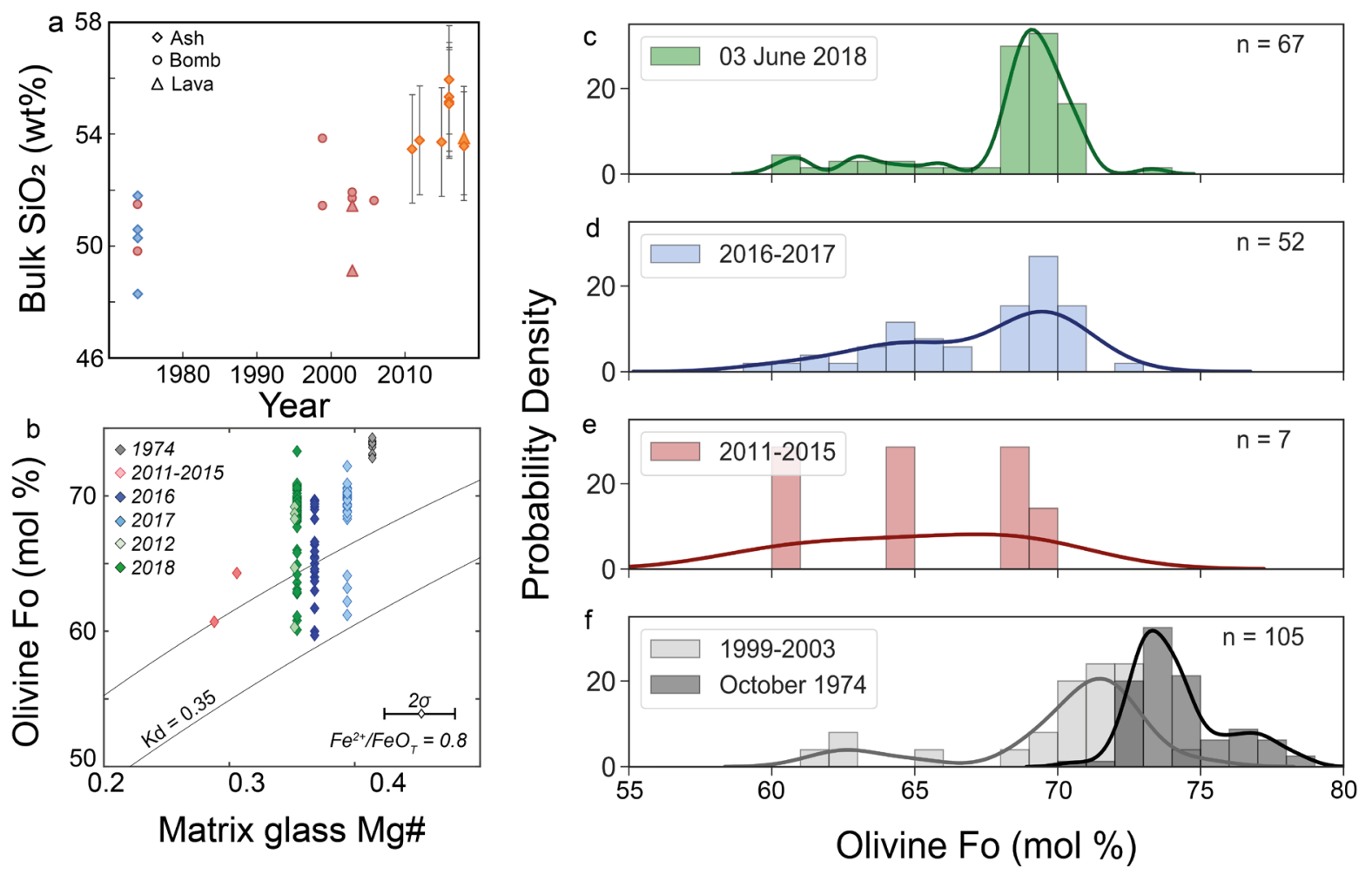

308

309

Figure 2: Mineral and bulk rock compositions. (a) Bulk rock compositions through time (additional data are presented in Table A.2). Data are compiled from Rose et al. (1978; blue symbols), Berlo et al. (2012); red symbols) and this study (orange symbols). Error bars report

312 the standard error. (b) Olivine core compositions versus mean glass Mg\#. The dashed and solid

313 lines indicate crystal-melt equilibria (where $\left.K_{\mathrm{D}}=\left(X_{\mathrm{FeO}} / X_{\mathrm{MgO}}\right)_{\text {olivine }} /\left(X_{\mathrm{FeO}} / X_{\mathrm{MgO}}\right)_{\mathrm{melt}}\right)$ of 0.27

314 (Matzen, 2011) and 0.35 (Roeder, 1970) for olivine/liquid, respectively. The horizontal error

315 bar represents two standard deviations on the mean glass Mg\#. (c-f) Distribution of olivine Fo 316 contents (cores) for different sampling periods, expressed as probability density functions. Data 317 for October 1974 are compiled from Lloyd et al., (2014), Berlo et al., (2012), and this study. Data for 1999-2003 are from Berlo et al., (2012). 
320 The groundmass crystallinity is dominated by plagioclase. We identify two main textures

321 distinguished by differences in plagioclase abundance and morphology. Texture A contains

322 relatively even proportions of all mineral phases, each with equant crystal morphologies (Fig.

323 3a). Compositional zoning is ubiquitous in plagioclase microphenocrysts $>100 \mu \mathrm{m}$, expressed

324 as an anorthite-rich core surrounded by a more sodic rim. Texture B is dominated by lath-like

325 unzoned plagioclase (Fig. 3b) with additional phases present as microphenocrysts in minor

326 proportions. Many plagioclase laths have swallowtail morphologies surrounded by a thin

327 immiscible compositional boundary layer (CBL) rich in plagioclase-incompatible elements,

328 notably iron (Fig. 3g-i). CBLs are maintained as long as crystal growth rates equal or exceed

329 elemental diffusion rates in the surrounding liquid (Honour et al., 2019). All ash samples

330 contain variable proportions of both textures. Texture A is most prevalent in ash particles from

3312011 through 2017. Ash particles from the 3 June 2018 eruption are dominated by texture B,

332 but exhibit greater textural variation than observed in other samples (Fig. 3c, d). In lava samples

333 from 2012, Texture A is exclusively associated with glomerocrysts. These two textural types

334 have also been observed in larger clasts from the 1974 eruption (Cashman and Edmonds, 2019). 

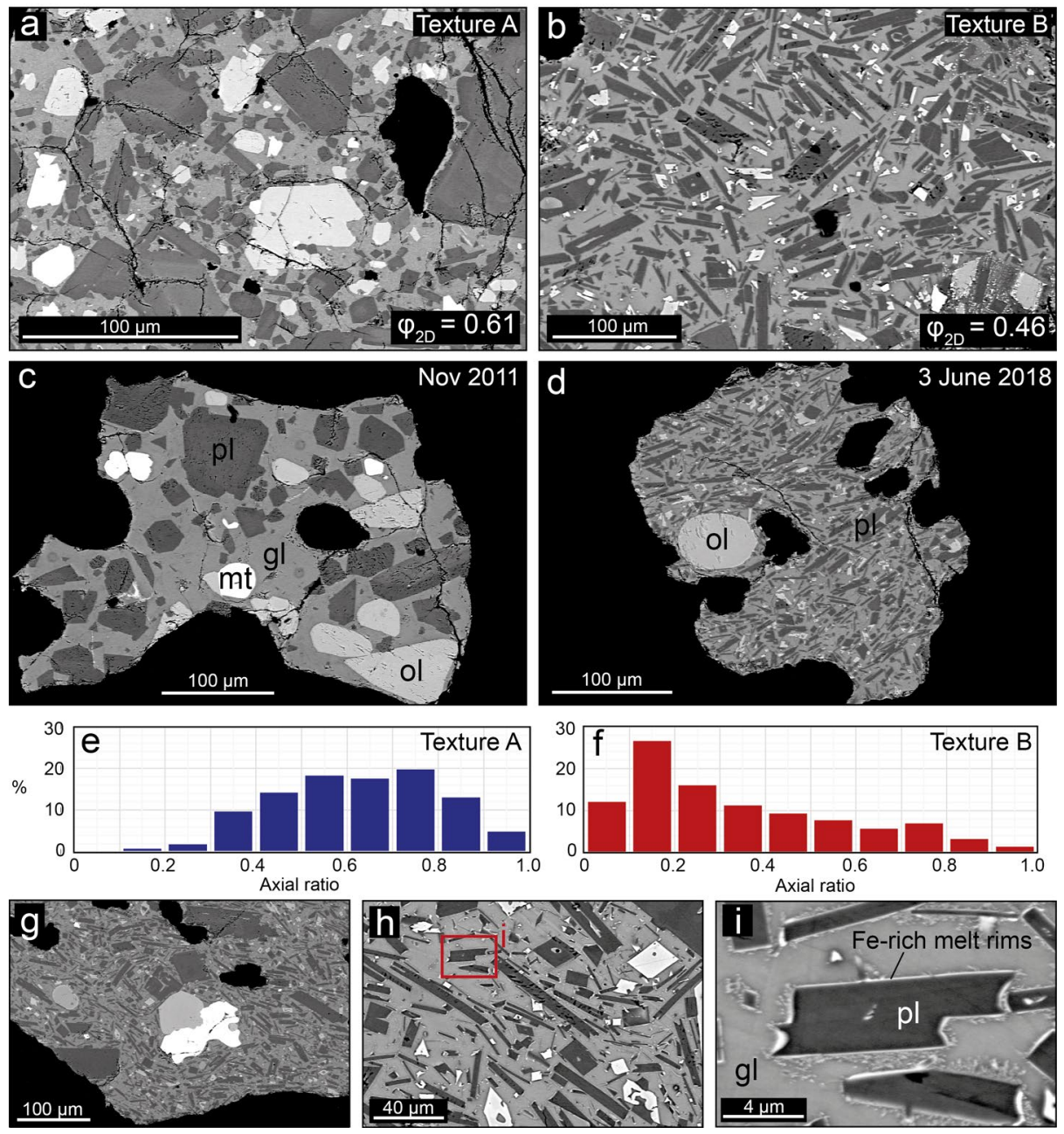

337 Figure 3: Ash textures. Backscattered electron scanning electron microscope (BSE-SEM) images of the two textural populations - (a) Texture A and (b) Texture B - expressed as differences in total crystallinity and crystal morphology. (a, b) Textures A and B from the 500$1000 \mu \mathrm{m}$ size fraction of the 3 June 2018 ash deposit. $92 \mathrm{D}$ refers to 2D (area-based) crystallinity,

341 where melt area is calculated on a vesicle-free basis. (c, d) Clasts representative of the dominant 342 texture in Nov 2011 and 3 June 2018, respectively, in the 250-500 $\mu \mathrm{m}$ size fraction. (e, f) Axial ratio (AxlR) distributions for Textures $\mathrm{A}$ and $\mathrm{B}$ measured from the images shown in (a) and (b) respectively. (g-i) Disequilibrium crystal growth textures shown by a sequence of BSESEM images acquired at increasing magnification in a Texture B clast from 3 June 2018. 
Matrix glass compositions are more evolved than their bulk rock equivalents (Table A.4), and 1974 glass compositions are distinct from 2011-2018 ash samples in all major elements. Glasses from samples erupted between 2011 and 2018 are andesitic in composition and span a relatively narrow range in $\mathrm{SiO}_{2}$ from 61.0 to $62.5 \mathrm{wt} \%$ (compared to $53.5-56.0 \mathrm{wt} \%$ of the bulk rocks) and $\mathrm{MgO}$ from 1.65 to $2.12 \mathrm{wt} \%$ (compared to $2.6-3.6 \mathrm{wt} \%$ of the bulk rocks). Within this range, however, we identify a step-change transition in the glass composition of erupted samples between 2015 and 2016. 2016-onward glasses have elevated $\mathrm{MgO}$ and reduced $\mathrm{K}_{2} \mathrm{O}$ relative to preceding years, with the notable exception of 13 Sept 2012 (Fig. 4a,b), as well as elevated concentrations of plagioclase-compatible major elements such as $\mathrm{CaO}$ and $\mathrm{Al}_{2} \mathrm{O}_{3}$ (Fig. A.4). In contrast, all samples between 2011-2018 share similar concentrations of olivinecompatible elements such as FeO (Fig. A.4). From 2016 to 2017, glass compositions remain stable and exhibit low inter-eruptive variability in major element abundances. For example, one standard deviation in $\mathrm{MgO}$ between all glass samples is only $0.17 \mathrm{wt} \%$ (and $0.74 \mathrm{wt} \%$ for $\mathrm{K}_{2} \mathrm{O}$ ). Glasses from ash erupted during the large paroxysmal events of 13 Sept 2012 and 3 June 2018 , in contrast, conform to their respective pre- or 2016-onward major element compositions only in selected elements. For example, the $\mathrm{MgO}$ content of the 2012 glass is more similar to the 2016-onward glasses, whilst the $\mathrm{K}_{2} \mathrm{O}$ content of the 2018 glass is more comparable to the pre-2016 compositions.

In multivariate space, ash samples divide into four distinct 'clusters' based on major element glass compositions (Fig. 4c). Glasses from the 1974 eruption are distinct from all 2011-2018 ash samples and form a cluster of size 1 . The next most significant divide is between pre- and 2016-onward samples, with the exception of 13 Sept 2012. The 2016-onward cluster then further subdivides, separating ash from the paroxysms on 3 June 2018 and 13 Sept 2012 from all other 2016-onward samples. Considering all major elements together, we find that glasses 


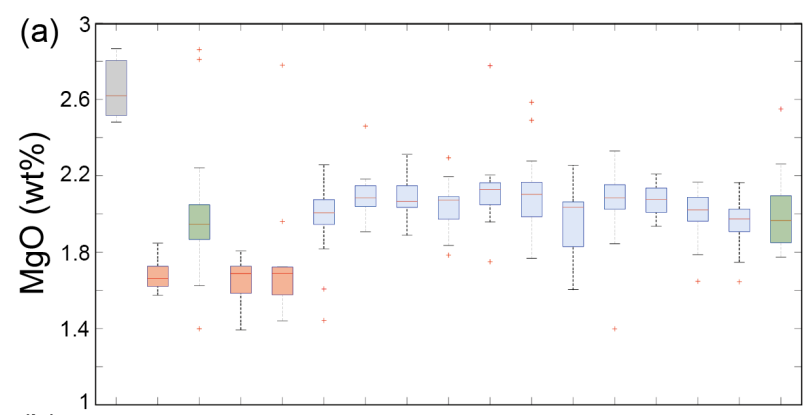

(b)

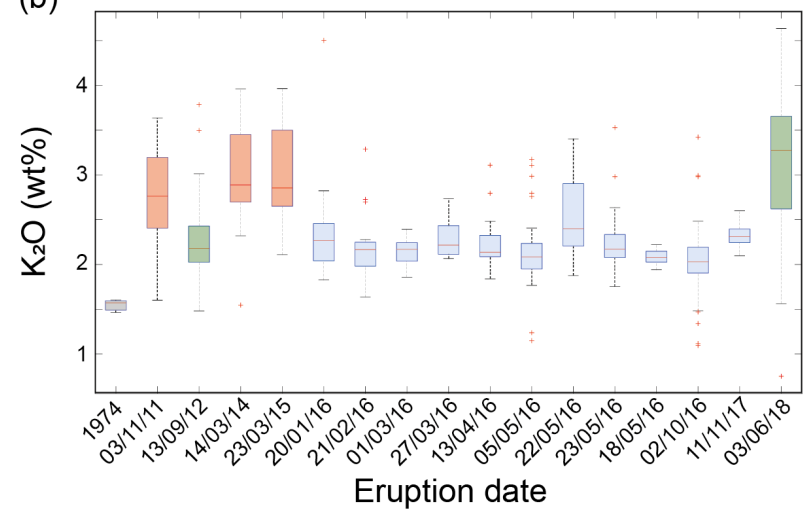

(c)

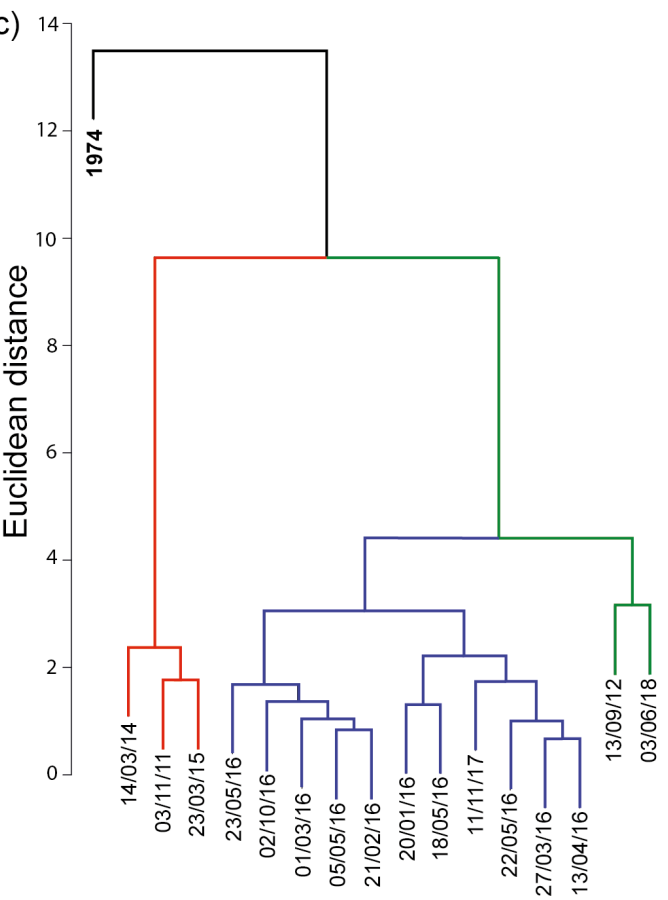

377 Figure 4: Glass compositions. $(a, b)$ Boxplots show the variation in matrix glass composition

378 through time (additional data are presented in the supplementary material). The median value 379 is shown by the red horizontal line, upper and lower quartiles are delimited by the box 380 dimensions, and the $99 \%$ confidence interval is indicated by the whisker length. Red crosses 381 represent outliers. (c) Cluster dendrogram showing inter-sample relatedness, calculated using 382 the Ward method (minimal variance) of hierarchical clustering (Ward, 1963). 
The erupted bulk magma composition at Fuego remained relatively consistent between 2011 and 2018, despite significant changes in both the frequency and intensity of paroxysmal eruptions over the same time period. This stability is superimposed on a long-term trend towards more evolved bulk compositions from 1974 through 1999-2003 to present (Berlo et al., 2012). Similarly, the modal phase compositions of olivine phenocrysts (and also plagioclase, although fewer literature data are available for comparison) have remained consistent since 2011, following a progressive transition towards more forsteritic compositions since 1974 (Fig. 2c-f). Here we discuss the possible mechanisms to explain elevated paroxysm frequency within the constraints provided by time series glass data, and in the context of both ash textures and long-term bulk and phase compositions.

\subsection{Isothermal decompression modulates the erupted glass composition}

Glass compositions reflect variable degrees of olivine + plagioclase + two pyroxene + magnetite crystallisation from the bulk starting composition. We modelled equilibrium crystallisation paths using Rhyolite-MELTS under a range of pressure-temperature conditions from different starting compositions to explore the processes responsible for the range in observed matrix glass compositions. These models are presented and discussed in detail in the Supplementary Materials (Appendix B and Table A.6).

The liquid composition in $\mathrm{MgO}-\mathrm{K}_{2} \mathrm{O}$ space is most sensitive to the pressure-temperature regime - isothermal decompression (ITD) or isobaric cooling (IBC) — controlled largely by the amount of mafic phases crystallising relative to plagioclase feldspar; changes in initial water content or redox buffer (from NNO to FMQ) do not alter the crystallisation paths appreciably (Figs A.9-11, supplementary materials). Modelled melt composition paths during isothermal decompression reproduce most closely the range and trend of glass compositions 
erupted at Fuego during 2011-2018, as was found for those erupted in 1974 (Cashman and

410 Edmonds, 2019). Each isotherm describes a steeply inclined path in a $\mathrm{K}_{2} \mathrm{O}-\mathrm{MgO}$ bi-plot, where small changes in $\mathrm{MgO}$ are accompanied by large changes in $\mathrm{K}_{2} \mathrm{O}$ (Fig. 5). The compositions

412 of glasses erupted from 2016 onward are best described by decompression paths at $1000^{\circ} \mathrm{C}$, 413 whilst pre-2016 glasses parallel an isotherm intermediate between $950^{\circ} \mathrm{C}$ and $1000^{\circ} \mathrm{C}$ at slightly higher $\mathrm{K}_{2} \mathrm{O}$. The step-change transition in glass composition between pre- and 2016onward glasses therefore records a shift to higher melt temperatures and reduced crystallisation (i.e., faster and deeper decompression). Importantly although we model decompression from $400 \mathrm{MPa}$ to $10 \mathrm{MPa}$, the steep gradient in $\mathrm{K}_{2} \mathrm{O}$ corresponding to plagioclase crystallisation typically does not begin until lower pressures $\left(\sim 150 \mathrm{MPa}\right.$ at $1000{ }^{\circ} \mathrm{C}$; Fig. $\left.5 \mathrm{~b}\right)$ and is independent of the starting pressure. Ash erupted during the energetic paroxysm on 13 September 2012 more closely resembles 2016-onward samples, with matrix glass compositions characterised by similar high $\mathrm{MgO}$ and low $\mathrm{K}_{2} \mathrm{O}$ compositions.

Horizontal shifts in the position of ITD paths along the $\mathrm{MgO}$ axis can be explained by varying amounts of IBC at depth, prior to ascent, which is dominated by crystallisation of mafic phases until plagioclase saturation (Fig. A.9, supplementary materials); the $\mathrm{MgO}$ content at which plagioclase saturation occurs depends strongly on the crystallisation pressure (Cashman and Edmonds, 2019). At high pressures (200-400 MPa), models show large changes in $\mathrm{MgO}$ for very little change in $\mathrm{K}_{2} \mathrm{O}$, whereby crystallisation of plagioclase is suppressed to low pressures (Fig. A.9). We therefore suggest, based on our modelling, that the trends we observe in our matrix glass data are consistent with variable degrees of IBC at depth, followed by ITD and 430 the resultant decompression-crystallisation of plagioclase. The shift to higher melt 431 temperatures recorded between pre- and 2016-onward glasses thus indicate reduced cooling (i.e. potentially a shorter storage duration at depth) prior to decompression. 
433 Melt fractionation due to the growth of mafic phases (e.g., olivine), in contrast, exerts a limited 434 influence on erupted glass compositions. The two modes at Fo68-70 and Fo62-64 remain relatively constant from 2011 through 2018, independent of variations in glass composition; this stability 436 further reinforces that variation in $\mathrm{K}_{2} \mathrm{O}$ is largely controlled by changes in plagioclase 437 crystallisation. Modal olivine core compositions are slightly more primitive than theoretical equilibria predict based on the $\mathrm{Mg} \#$ of the host glass (Fig. 3e), indicating crystallisation from less fractionated melts, while compositional gradients shown by core-to-rim profiles suggest that olivine rims approach theoretical equilibrium.

441 Samples from 3 June 2018 are geochemically distinct (Fig. 5). Glass compositions parallel the same isotherm as the 2016-onward population but extend further along the crystallisation path. This expanded range, manifest largely as variation in $\mathrm{K}_{2} \mathrm{O}$, requires samples with a wide range of (groundmass) plagioclase crystallinity, which in turn implies decompression-driven crystallisation over a range of pressures (depths). These samples also have crystal textures that populate a spectrum between A (equant) and B (acicular, skeletal) end members (Fig. 3). Total microlite crystallinity is inversely related to average volumetric eruption rate in natural samples (e.g., Tungurahua; Wright et al., 2012) and to integrated decompression rate in experimental data (e.g. Soufriere Hills Volcano, Couch et al., 2003; Arenal, Szramek et al., 2006). Microlite crystallinity can therefore be considered a relative proxy for decompression rate, although the exact relationship between these two parameters will be composition- and temperaturedependent (Wright et al., 2012). Further, experimental data show that elongate (acicular) crystals - typical of texture B in our samples - record fast growth rates associated with high rates of decompression (Hammer and Rutherford, 2002). The mixture of crystal textures A and B in 2018 ash samples provides further support for a range of decompression rates. 

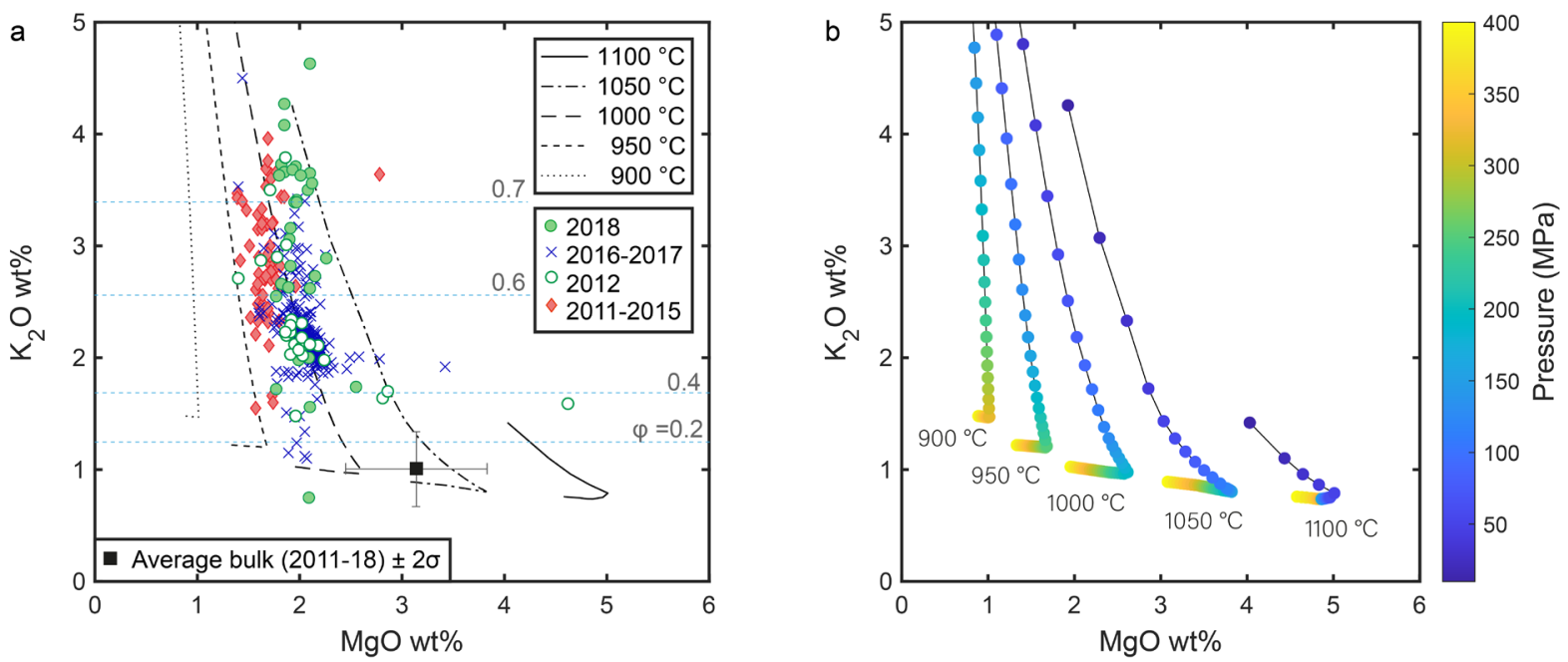

457

Figure 5: Modelling crystallisation pathways. Evolution of melt composition $\left(\mathrm{K}_{2} \mathrm{O}\right.$ versus

$\mathrm{MgO}$ ) during isothermal decompression for an $\mathrm{H}_{2} \mathrm{O}$-rich arc basalt. (a) Measured glass compositions for Fuego (Table A.4) are compared to modelled melt compositional paths calculated using Rhyolite-MELTS. The model was initiated with a starting bulk composition from 1974 (Rose et al., 1978), with $4.5 \mathrm{wt} \% \mathrm{H}_{2} \mathrm{O}$ and $\mathrm{fO}_{2}$ of $\mathrm{NNO}$, for temperatures between 900 and $1100^{\circ} \mathrm{C}$ in $50^{\circ} \mathrm{C}$ increments and decompression from 400 to $10 \mathrm{MPa}$ (following Cashman and Edmonds, 2019). Dashed lines represent contours of crystallisation, calculated from the average glass $\mathrm{K}_{2} \mathrm{O}$ content in each group and the average bulk composition (20112018), assuming $\mathrm{K}_{2} \mathrm{O}$ is perfectly incompatible. (b) Model runs shown in (a) coloured according to pressure along the isothermal decompression path. The pressure at which the steep gradient in $\mathrm{K}_{2} \mathrm{O}$ begins is linked to the onset plagioclase crystallisation and is inversely related to the melt temperature. For example, for a melt temperature of $1000^{\circ} \mathrm{C}, \mathrm{K}_{2} \mathrm{O}$ begins to increase rapidly at $\sim 150 \mathrm{MPa}$ and is independent of the range of simulated decompression. 
473 The step-change in glass composition between 2015 and 2016 occurs concurrently with an 474 escalation in the frequency of paroxysmal activity (Fig. 1b; Naismith et al., 2019). More 475 frequent paroxysms imply an enhanced magma flux through the shallow conduit, consistent 476 with higher melt temperatures. Our data show that any model to explain the increase in 477 paroxysm frequency must satisfy three observations: (1) an increase in melt temperature; (2) a reduction in pre-eruptive crystallisation (i.e. faster and deeper decompression), and, critically, 479 (3) no change in the bulk composition.

Paroxysmal eruptions of mafic arc volcanoes have been attributed to increases in either magma flux or gas flux (e.g., Viccaro et al., 2014). Introduction of new (hotter and more primitive) magma would manifest as a change in the bulk chemistry towards more basaltic compositions. The 2011-2018 Fuego samples, in contrast, have more evolved bulk compositions than samples from 1974, or even 1999-2003 (Fig. 2a). Further, the compositions of key mineral phases remain unchanged from 2011 through 2018. We therefore suggest that our data support gas-driven modulation of paroxysmal activity, where exsolved volatiles are supplied by unerupted magmas undergoing second boiling (crystallisation and degassing) in the lower to mid-crust. In this model, the frequency and intensity of explosive eruptions are controlled by changes in degassing behaviour-a function of both the gas supply rate and the permeability of the shallow conduit to gas escape-with no change to the bulk magma composition.

The two models are not mutually exclusive, as the introduction of primitive volatile-rich magma to a lower crustal reservoir would provide a feasible source of the additional exsolved volatiles, assuming gas-melt separation occurs at depth. The extent and location of gas separation, in turn, will depend on the initial volatile content of the melt, the kinetics of vesiculation and the efficiency of separated gas flow. The volatile content of the 1974 Fuego magma is well constrained at $\leq 6.5 \mathrm{wt} \% \mathrm{H}_{2} \mathrm{O}$ (Roggensack, 2001) and $\leq 2500 \mathrm{ppm} \mathrm{CO}_{2}$ (glass

497 + bubble; Moore et al., 2015). Such high volatile contents would allow gas saturation at mid- 
to lower crustal levels ( $>500 \mathrm{MPa}$ ) prior to extensive crystallisation. Volatile contents of more

499

500

501

502

503

504

505

506

507

508

509

510

511

512

513

514

515

516

517

518

519

520

521

522 recent Fuego magmas are less well constrained, although application of an $\mathrm{Al}_{2} \mathrm{O}_{3}$ hygrometer (Parman et al., 2011) suggests $\mathrm{H}_{2} \mathrm{O}$ contents of at least $5.5 \mathrm{wt} \%$ in the 2012 magma (Cashman and Edmonds, 2019) and $\leq 1700$ ppm $\mathrm{CO}_{2}$ in samples from 1999 and 2003 (glass only; Berlo et al., 2012).

Additional insight comes from the repeated pattern of eruptive activity, where protracted lava effusion precedes paroxysmal activity. This sequence has also been observed at Stromboli volcano, Italy. One difference is that at Stromboli in 2003 and 2007, the lava effusion occurred from a vent below the summit, which suggests drainage of the conduit magma as a mechanism for decompressing magma at depth (Ripepe et al., 2017, 2015). At Fuego, in contrast, effusion is from the summit, which requires an increase of magma volume in the conduit. Although this volume increase could reflect increased magma supply, it could also be the result of an increase in gas supply, such that the volume of magma in the conduit increases but the mass does not. In the engineering literature, this is referred to as the "gas holdup", which increases with gas flux (Akita and Yoshida, 1973; Aslan et al., 2006). Analogue experiments show that the gas holdup is also affected by the presence of crystals (Belien et al., 2010; Oppenheimer et al., 2020). When the crystal content is $<\sim 30 \%$, bubbles can easily rise through the melt. At higher crystal contents, degassing may be enhanced via connected (permeable pathways); at very high crystallinities, bubbles can become trapped within the suspension, thus adding to the volume. If we treat $\mathrm{K}_{2} \mathrm{O}$ as perfectly incompatible, then average glass $\mathrm{K}_{2} \mathrm{O}$ contents translate to crystallinities of $55 \pm 32[2 \sigma] \%$ and $54 \pm 25[2 \sigma] \%$ for the 2012 and 2016-onward magma, compared with crystallinities of $64 \pm 32[2 \sigma] \%$ and $66 \pm 44[2 \sigma] \%$ for the $2011-2015$ and 2018 magma (see crystallinity contours on Fig. 5). These values are within the range of 2D (area-based) crystallinities measured from the SEM images shown in Figure $3\left(\varphi_{2 \mathrm{D}}=46-61 \%\right)$, even considering the large uncertainties associated with $2 \mathrm{D}$ to $3 \mathrm{D}$ conversion, and exceed 
experimental thresholds for a crystal control on gas migration (Belien et al., 2010;

524 Oppenheimer et al., 2020).

525 A role for deeply-derived gas in modulating surface activity has been suggested for other mafic arc volcanoes including Villarrica volcano (Chile), which hosts an open lava lake at its summit. Here, variations in the magma level within the conduit are manifest as changes in lava lake level, and broadly correlated with both gas flux and seismicity over months to years (Palma et al., 2008; Romero et al., 2018). Magma high-stands are accompanied by more vigorous bubblebursting activity, elevated $\mathrm{SO}_{2}$ emission rates, more frequent long-period seismic events and increased satellite detection of thermal anomalies. Paroxysms are less frequent than at Fuego, but an intense paroxysmal eruption on 3 March 2015 generated a sustained $1.5 \mathrm{~km}$-high lava fountain. This eruption followed three years of relative quiescence during which the magma had resided out of sight deep in the conduit. In the days prior to the climactic event, the magma level rose rapidly from $120-130 \mathrm{~m}$ below the crater rim to $<70 \mathrm{~m}$, after which Strombolian activity intensified before transitioning to lava fountain activity (Johnson et al., 2018). Precursory changes in the gas chemistry signalled an increase in the supply of $\mathrm{CO}_{2}$-rich gas from depth (Aiuppa et al., 2017), similar to that observed before escalations in activity at other mafic arc volcanoes (e.g., Aiuppa et al., 2010; de Moor et al., 2016). We note that erupted pyroclasts from this eruption at Villarrica generally have lower crystallinities than those from Fuego-from $3 \%$ (scoria lapilli) to $65 \%$ (spatter and mixed avalanche deposits) — and exhibit a narrower range in matrix glass $\mathrm{K}_{2} \mathrm{O}(<1 \mathrm{wt} \%$; Romero et al., 2018); these properties suggest crystallisation under different pressure-temperature conditions and initial dissolved volatile contents than the model runs shown in Figure 5 based on Fuego bulk compositions.

545 Although the repose times between paroxysmal events differ there are several parallels to be 546 drawn between Villarrica and Fuego. First, gas holdup can explain the observed coupling 547 between magma level and gas flux. At Fuego, this additional gas pressure forces effusion, while 
at Villarrica the increased volume within the open conduit is accommodated by a rise in lake level. Second, evidence for deeply-derived gas may help to explain the driving mechanism for the escalation in the frequency of paroxysms at Fuego 2016-onward. Finally, a progression

551 from Strombolian into paroxysmal lava fountain activity and back again is common not only 552 to these two volcanoes but is also a widespread behaviour (including the 64 eruptions of Etna's southeast crater in 2000; Alparone et al., 2003). Paroxysmal activity therefore appears to represent an end member in the common spectrum of eruptive activity at hydrous mafic open system volcanoes, transitions we suggest are largely governed by the gas supply. Our time series petrologic data for Fuego show in detail how changes in magma temperature and decompression parameters, evidenced by glass chemistry, correlate with eruption frequency, and, when interpreted in the context of bulk and phase compositions, can distinguish between gas- and recharge-driven end-members of paroxysmal activity.

\subsection{The eruption of 3 June, 2018}

562 The eruption of Fuego on 3 June 2018 was the most damaging since the VEI 4 eruption of 1974. This eruption was unusual for the speed of its progression: paroxysmal activity 564 (including lava fountaining and pyroclastic flows) commenced only six hours after lava flows began and the eruption rate accelerated abruptly several hours after the onset of lava fountaining (Naismith et al., 2019; Pardini et al., 2019). The precursory lava flows were

567 unusually hot, moved quickly and advanced several kilometres in a matter of hours. This behaviour contrasts with more viscous flows in May 2018, which moved slowly and achieved

569 lengths of only a few hundred metres from the vent and did not transition to paroxsymal 570 activity. 
571 Prior to June 2018, the frequency of paroxysmal eruptions at Fuego had begun to decline and 572 indeed the regular cyclicity that had been so striking during 2016 had broken down by mid- to 573 late-2017. Only one paroxysm was reported in early 2018 (Naismith et al., 2019). We propose 574 that this relative hiatus in activity signalled a system-scale reduction in the gas supply. The 5575 month hiatus in activity that preceded the 3 June 2018 eruption would have allowed sufficient time for crystallisation of a shallow low permeability plug. Indeed, the viscous flows extruded slowly in April and May 2018 are consistent with densification of magma in the shallow part of the conduit.

Gas accumulation beneath a low permeability plug in the upper conduit is also invoked to explain the high intensity of the Vulcanian eruptions common in volcanoes typified by hydrous magmas of intermediate to silicic compositions. Plug failure and subsequent downward propagation of a decompression wave rapidly ejects magma from a vertical section of the conduit (e.g., Alidibirov and Dingwell, 1996; Diller et al., 2006; Druitt et al., 2002; Gaunt et al., 2020; Miwa et al., 2013; Wright et al., 2007). The result is a wide range of pyroclast crystallinity, vesicularity and occasionally clast morphology (e.g., Sakurajima, Miwa et al., 2013; Tungurahua, Battaglia et al., 2019). Short-lived Vulcanian explosions can transition to sub-Plinian eruptions if decompression is balanced by magma ascent, or continuous ash emission if unloading promotes extensive degassing (Cassidy et al., 2015; Edmonds et al., 2003; Edmonds and Herd, 2007; Iguchi et al., 2008).

A range of glass compositions (crystallinity) and textures also characterises the 3 June 2018 samples (Figs. 3, 4). We therefore hypothesise that this event shared features common to Vulcanian eruptions generated by failure of a shallow conduit plug. Although the paroxysm itself appeared to initiate in a similar, albeit faster, sequence to previous eruptions, progressive degradation and eventual failure of a (now only partially intact) dense plug would explain the abrupt escalation in explosive vigour several hours into the eruption. Rapid top-down 
decompression also explains the extensive vertical evacuation of the conduit indicated by the ash textural and compositional variability.

\subsection{Implications for future eruptive activity at Fuego}

An interesting outcome of our time series analysis is that it shows that on a multi-decadal timescale the bulk rock composition is becoming more evolved through time (Fig. 2a). As noted above, this trend contrasts with the observed variations in glass (melt) composition. It also appears to continue the trend noted by Berlo et al. (2012), who used (primarily) melt inclusion data to suggest that (1) the 1974 eruption may have been triggered by intrusion of a new, and more primitive, magma batch into the resident (more evolved) magma reservoir, and (2) that magma erupted in 1999 and 2003 was remnant from the 1974 activity.

The increase in frequency of paroxysms in 2016 raised questions about whether the volcano was heading toward another VEI 4 eruption similar to that witnessed in 1974. If mafic recharge was responsible for the escalation in paroxysm frequency through 2015 then we would expect to see petrological evidence of primitive magma intrusion in the form of mixing/mingling textures or more primitive bulk compositions, evidence that is lacking in the 2011-2018 data. Although petrological signatures of mafic recharge were not reported in products erupted prior to the 1974 eruption, neither was the style of regular paroxysmal activity characteristic of recent years.

The change in activity in 2018 prompted consideration of additional scenarios for future activity. These scenarios included a return to 2016 paroxysm frequency, an increase in eruption intensity, or a decline in eruptive activity (Naismith et al., 2019). Our data suggest that the latter possibility is the most likely. In the context of a gas-driven model for paroxysmal activity, 
where gas is supplied by deep degassing of lower crustal magmas, a return to the frequent paroxysmal activity of 2016-2017 would seem to require a new influx of gas from depth. Although this is likely in the future, the pattern of declining paroxysm frequency in late 2017 and early 2018 suggests that the gas batch driving the recent increase in paroxysms had started to decline prior to the 3 June 2018 eruption, although timescales for ascent of the proposed deeply-exsolved volatile phase are unconstrained by the available data. Similarly, we see no evidence from the ash samples of the new magma or gas input required to increase the eruptive intensity and/or frequency. Therefore, we think it most likely that the volcano will return to patterns of activity characteristic of 2011-2015.

In a global context, our work provides new insight into transitions in eruptive activity in mafic arc volcanoes. In silicic systems, the climactic phase typically occurs early on in the sequence, most often in the first quarter of an eruptive period, and shows a progression from explosive to effusive activity as overpressure decreases through time (Cassidy et al., 2018). In mafic systems, however, a protracted period of lava effusion preceding paroxysmal activity appears to be a recurrent theme, placing the emphasis on effusive to explosive transitions. Indeed, our observations suggest that lava effusion as mechanism of top-down decompression, as previously suggested for Stromboli (Calvari et al., 2011; Ripepe et al., 2015), may be a prevalent feature of mafic paroxysmal activity.

Cyclical behaviour in paroxysmal activity is reported at many mafic arc volcanoes (e.g., Alparone et al., 2003; Hall et al., 2015; Lyons et al., 2010), although over various timescales. This periodicity is often attributed to two phase models involving repeated foam accumulation and collapse (Vergniolle and Jaupart, 1986). Indeed, the low viscosities of mafic magmas may allow effective gas-melt segregation, but also promote extensive decompression-driven crystallisation. Importantly, two-phase flow models are not appropriate for crystal-rich magmas, where gas storage and escape are strongly modified by the abundance and 
connectivity of the crystals (Barth et al., 2019; Belien et al., 2010; Lindoo et al., 2017;

645 Oppenheimer et al., 2020, 2015; Suckale et al., 2016). We therefore emphasise that a crystal

646

647

648

649

650

652

653

654

655

656

657

658

659

660

661

662

663

664

665

666

667 control on gas permeability is likely to be pervasive, and that pulses of elevated paroxysm frequency can be explained by feedbacks within magmatic systems without the need to invoke repeated transfer of new magma to a shallow reservoir.

Finally, our sequential ash observations reinforce the application of time series petrologic data not only for analysis of what happened in the past (e.g., Miwa et al., 2013; Taddeucci et al., 2002; Wright et al., 2012), but also for forecasts of future eruptive behaviour (Gansecki et al., 2019). In particular, petrologic monitoring data can provide critical insight to distinguish between gas- and magma-driven paroxysm triggers and consequently the probable evolution that future activity may take, especially when interpreted in the context of geophysical observations (e.g., Taddeucci et al., 2002; Viccaro et al., 2015, 2014). Further, we demonstrate the value of community-based ash collection networks and protocols (Bernard, 2013) for obtaining good spatial and temporal coverage of ash samples, particularly for eruptions that are both frequent (and thus subject to a range of wind conditions) and of varying magnitude. Lower crustal degassing magmas that supply gas to shallow magmatic systems present challenges for surface monitoring; deep magma emplacement and upward fluid transfer through the crust take place largely unseen by measurements of ground deformation and seismicity, placing additional weight on gas flux and petrologic monitoring to detect the processes that modulate long-term trends in eruptive activity.

\section{CONCLUSIONS}

Fuego volcano, Guatemala, exhibits regular paroxysmal eruptions; the frequency and magnitude of these events has changed through time, however. Ash and lava samples collected 
largely through a community-based sampling initiative highlight a distinct change in glass composition pre-2016 and 2016-onward, which correlates with an abrupt escalation in paroxysm frequency. To explain an increase in melt temperature and a reduction in pre-eruptive crystallisation (i.e. faster and deeper decompression) with, importantly, no change to the bulk composition, we suggest that this increase in paroxysmal eruptions is modulated by the gas supply rate from degassing magmas in the lower crust, without invoking repeated transfer of new, primitive magma to a shallow reservoir. Protracted lava effusion - accompanied by more vigorous and more frequent Strombolian explosions and gas 'chugging' - prior to the transition to sustained lava fountaining suggests that gas holdup may modulate the height of the magma column as gas supply increases. Indeed, lava effusion may provide a mechanism of 'slow decompression' that initiates the paroxysmal phase, as proposed for other mafic arc volcanoes. Further, the extensive range of glass compositions (crystallinity) and textures erupted during the large paroxysmal eruption on 3 June 2018 suggests a mechanism that shared features common to Vulcanian eruptions, where magma is evacuated over a range of depths and decompression rates. The relatively long repose time between paroxysms prior to 3 June, together with the sluggish nature of lava effusion in the months prior, are consistent with the development of a low permeability shallow plug. We suggest that this plug degraded, and ultimately failed, several hours into the eruption of 3 June 2018, triggering top-down decompression of magma in the conduit synchronous with the observed rapid acceleration in eruption rate. Our data suggest that the frequency of paroxysms at mafic arc volcanoes is broadly proportional to the gas supply rate, whilst the range in glass compositions is related to the repose time prior to eruptive activity. Petrologic monitoring has huge potential to augment the insights provided by geophysical techniques and thus inform forecasts of future activity, especially when performed in near real-time and facilitated by community-based ash collection initiatives. 


\section{Acknowledgements}

696

697

698

699

700

701

702

703

704

705

706

707

708

709

710

711

712

713

714

715

716

717

718

719

720

We are extremely grateful for the hard work and kindness of the citizen volunteers, and the staff and observers at INSIVUMEH who enabled collection of these samples. We also thank Matt Watson, Matt Purvis of Geo Travel Guatemala, and the University of Bristol MSc Volcanology 2015-16 cohort for their invaluable field assistance during installation of the ash meters. We thank B. Bernard for valuable advice and discussion as we embarked on the community-based ash sampling. This work was funded by an Innovation Fund Award from the Cabot Institute for the Environment to EJL and KVC, a Leverhulme Early Career Fellowship to EJL, a NERC grant NE/P017045/1 to BEK and support to KVC by the AXA research fund and a Royal Society Research Wolfson Merit Award.

\section{References}

Aiuppa, A., Bitetto, M., Francofonte, V., Velasquez, G., Parra, C.B., Giudice, G., Liuzzo, M., Moretti, R., Moussallam, Y., Peters, N., Tamburello, G., Valderrama, O.A., Curtis, A., 2017. A CO2-gas precursor to the March 2015 Villarrica volcano eruption. Geochemistry, Geophysics, Geosystems 18, 2120-2132. https://doi.org/10.1002/2017GC006892

Aiuppa, A., Burton, M., Caltabiano, T., Giudice, G., Guerrieri, S., Liuzzo, M., Murè, F., Salerno, G., 2010. Unusually large magmatic $\mathrm{CO} 2$ gas emissions prior to a basaltic paroxysm. Geophysical Research Letters 37. https://doi.org/10.1029/2010GL043837

Akita, K., Yoshida, F., 1973. Gas Holdup and Volumetric Mass Transfer Coefficient in Bubble Columns. Effects of Liquid Properties. Ind. Eng. Chem. Proc. Des. Dev. 12, 76-80. https://doi.org/10.1021/i260045a015

Alidibirov, M., Dingwell, D.B., 1996. Magma fragmentation by rapid decompression. Nature 380, 146-148. https://doi.org/10.1038/380146a0

Allard, P., 2010. A CO2-rich gas trigger of explosive paroxysms at Stromboli basaltic volcano, Italy. Journal of Volcanology and Geothermal Research 189, 363-374. https://doi.org/10.1016/j.jvolgeores.2009.11.018

Aloisi, M., Jin, S., Pulvirenti, F., Scaltrito, A., 2017. The December 2015 Mount Etna eruption: An analysis of inflation/deflation phases and faulting processes. Journal of Geodynamics 107, 34-45. https://doi.org/10.1016/j.jog.2017.03.003 
Alparone, S., Andronico, D., Lodato, L., Sgroi, T., 2003. Relationship between tremor and volcanic activity during the Southeast Crater eruption on Mount Etna in early 2000. Journal of Geophysical Research: Solid Earth 108. https://doi.org/10.1029/2002JB001866

Andronico, D., Branca, S., Calvari, S., Burton, M., Caltabiano, T., Corsaro, R.A., Del Carlo, P., Garfi, G., Lodato, L., Miraglia, L., Murè, F., Neri, M., Pecora, E., Pompilio, M., Salerno, G., Spampinato, L., 2005. A multi-disciplinary study of the 2002-03 Etna eruption: insights into a complex plumbing system. Bull Volcanol 67, 314-330. https://doi.org/10.1007/s00445-004-0372-8

Andronico, D., Corsaro, R.A., 2011. Lava fountains during the episodic eruption of South-East Crater (Mt. Etna), 2000: insights into magma-gas dynamics within the shallow volcano plumbing system. Bull Volcanol 73, 1165-1178. https://doi.org/10.1007/s00445-011-0467-y

Aslan, M.M., Crofcheck, C., Tao, D., Pinar Mengüç, M., 2006. Evaluation of micro-bubble size and gas hold-up in two-phase gas-liquid columns via scattered light measurements. Journal of Quantitative Spectroscopy and Radiative Transfer, Light in Planetary Atmospheres and Other Particulate Media 101, 527-539. https://doi.org/10.1016/j.jqsrt.2006.02.068

Barth, A., Edmonds, M., Woods, A., 2019. Valve-like dynamics of gas flow through a packed crystal mush and cyclic strombolian explosions. Scientific Reports 9, 1-9. https://doi.org/10.1038/s41598-018-37013-8

Battaglia, J., Hidalgo, S., Bernard, B., Steele, A., Arellano, S., Acuña, K., 2019. Autopsy of an eruptive phase of Tungurahua volcano (Ecuador) through coupling of seismo-acoustic and $\mathrm{SO} 2$ recordings with ash characteristics. Earth and Planetary Science Letters 511, 223-232. https://doi.org/10.1016/j.epsl.2019.01.042

Belien, I.B., Cashman, K.V., Rempel, A.W., 2010. Gas accumulation in particle-rich suspensions and implications for bubble populations in crystal-rich magma. Earth and Planetary Science Letters 297, 133-140. https://doi.org/10.1016/j.epsl.2010.06.014

Berlo, K., Stix, J., Roggensack, K., Ghaleb, B., 2012. A tale of two magmas, Fuego, Guatemala. Bull Volcanol 74, 377-390. https://doi.org/10.1007/s00445-011-0530-8

Bernard, B., 2013. Homemade ashmeter: a low-cost, high-efficiency solution to improve tephra fielddata collection for contemporary explosive eruptions. J Appl. Volcanol. 2, 1. https://doi.org/10.1186/2191-5040-2-1

Bertagnini, A., Métrich, N., Landi, P., Rosi, M., 2003. Stromboli volcano (Aeolian Archipelago, Italy): An open window on the deep-feeding system of a steady state basaltic volcano. Journal of Geophysical Research: Solid Earth 108. https://doi.org/10.1029/2002JB002146

Calvari, S., Spampinato, L., Bonaccorso, A., Oppenheimer, C., Rivalta, E., Boschi, E., 2011. Lava effusion - A slow fuse for paroxysms at Stromboli volcano? Earth and Planetary Science Letters 301, 317-323. https://doi.org/10.1016/j.epsl.2010.11.015

Cashman, K.V., Edmonds, M., 2019. Mafic glass compositions: a record of magma storage conditions, mixing and ascent. Phil. Trans. R. Soc. A 377, 20180004. https://doi.org/10.1098/rsta.2018.0004

Cashman, K.V., Hoblitt, R.P., 2004. Magmatic precursors to the 18 May 1980 eruption of Mount St. Helens, USA. Geology 32, 141-144. https://doi.org/10.1130/G20078.1

Cashman, K.V., McConnell, S.M., 2005. Multiple levels of magma storage during the 1980 summer eruptions of Mount St. Helens, WA. Bull Volcanol 68, 57. https://doi.org/10.1007/s00445005-0422-x

Cashman, K.V., Taggart, J.E., 1983. Petrologic Monitoring of 1981 and 1982 Eruptive Products from Mount St. Helens. Science 221, 1385-1387. https://doi.org/10.1126/science.221.4618.1385

Cassidy, M., Cole, Paul.D., Hicks, K.E., Varley, N.R., Peters, N., Lerner, A.H., 2015. Rapid and slow: Varying magma ascent rates as a mechanism for Vulcanian explosions. Earth and Planetary Science Letters 420, 73-84. https://doi.org/10.1016/j.epsl.2015.03.025

Cassidy, M., Manga, M., Cashman, K., Bachmann, O., 2018. Controls on explosive-effusive volcanic eruption styles. Nature Communications 9, 1-16. https://doi.org/10.1038/s41467-01805293-3 
Chesner, C.A., Rose, W.I., 1984. Geochemistry and evolution of the fuego volcanic complex, Guatemala. Journal of Volcanology and Geothermal Research 21, 25-44. https://doi.org/10.1016/0377-0273(84)90014-3

Corsaro, R.A., Di Renzo, V., Distefano, S., Miraglia, L., Civetta, L., 2013. Relationship between petrologic processes in the plumbing system of Mt. Etna and the dynamics of the eastern flank from 1995 to 2005. Journal of Volcanology and Geothermal Research, Flank instability at Mt. Etna 251, 75-89. https://doi.org/10.1016/j.jvolgeores.2012.02.010

Corsaro, R.A., Miraglia, L., 2005. Dynamics of 2004-2005 Mt. Etna effusive eruption as inferred from petrologic monitoring. Geophysical Research Letters 32. https://doi.org/10.1029/2005GL022347

Corsaro, R.A., Miraglia, L., Pompilio, M., 2007. Petrologic evidence of a complex plumbing system feeding the July-August 2001 eruption of Mt. Etna, Sicily, Italy. Bull Volcanol 69, 401. https://doi.org/10.1007/s00445-006-0083-4

D’Aleo, R., Bitetto, M., Delle Donne, D., Coltelli, M., Coppola, D., McCormick Kilbride, B., Pecora, E., Ripepe, M., Salem, L.C., Tamburello, G., Aiuppa, A., 2019. Understanding the SO2 Degassing Budget of Mt Etna's Paroxysms: First Clues From the December 2015 Sequence. Front. Earth Sci. 6. https://doi.org/10.3389/feart.2018.00239

de Moor, J.M., Aiuppa, A., Pacheco, J., Avard, G., Kern, C., Liuzzo, M., Martínez, M., Giudice, G., Fischer, T.P., 2016. Short-period volcanic gas precursors to phreatic eruptions: Insights from Poás Volcano, Costa Rica. Earth and Planetary Science Letters 442, 218-227. https://doi.org/10.1016/j.epsl.2016.02.056

deGraffenried, R.L., Larsen, J.F., Graham, N.A., Cashman, K.V., 2019. The Influence of Phenocrysts on Degassing in Crystal-Bearing Magmas With Rhyolitic Groundmass Melts. Geophysical Research Letters 46, 5127-5136. https://doi.org/10.1029/2018GL081822

Diller, K., Clarke, A.B., Voight, B., Neri, A., 2006. Mechanisms of conduit plug formation: Implications for vulcanian explosions. Geophysical Research Letters 33. https://doi.org/10.1029/2006GL027391

Druitt, T.H., Young, S.R., Baptie, B., Bonadonna, C., Calder, E.S., Clarke, A.B., Cole, P.D., Harford, C.L., Herd, R.A., Luckett, R., Ryan, G., Voight, B., 2002. Episodes of cyclic Vulcanian explosive activity with fountain collapse at Soufrière Hills Volcano, Montserrat. Geological Society, London, Memoirs 21, 281-306. https://doi.org/10.1144/GSL.MEM.2002.021.01.13

Ebmeier, S.K., Biggs, J., Mather, T.A., Amelung, F., 2013. On the lack of InSAR observations of magmatic deformation at Central American volcanoes. Journal of Geophysical Research: Solid Earth 118, 2571-2585. https://doi.org/10.1002/jgrb.50195

Edmonds, M., Herd, R.A., 2007. A volcanic degassing event at the explosive-effusive transition. Geophysical Research Letters 34. https://doi.org/10.1029/2007GL031379

Edmonds, M., Oppenheimer, C., Pyle, D.M., Herd, R.A., Thompson, G., 2003. SO2 emissions from Soufrière Hills Volcano and their relationship to conduit permeability, hydrothermal interaction and degassing regime. Journal of Volcanology and Geothermal Research 124, 2343. https://doi.org/10.1016/S0377-0273(03)00041-6

Escobar-Wolf, 2013. Volcanic processes and human exposure as elements to build a risk model for Volcan de Fuego, Guatemala 216.

Gambino, S., Cannata, A., Cannavò, F., Spina, A.L., Palano, M., Sciotto, M., Spampinato, L., Barberi, G., 2016. The unusual 28 December 2014 dike-fed paroxysm at Mount Etna: Timing and mechanism from a multidisciplinary perspective. Journal of Geophysical Research: Solid Earth 121, 2037-2053. https://doi.org/10.1002/2015JB012379

Gansecki, C., Lee, R.L., Shea, T., Lundblad, S.P., Hon, K., Parcheta, C., 2019. The tangled tale of Kīlauea's 2018 eruption as told by geochemical monitoring. Science 366. https://doi.org/10.1126/science.aaz0147

Gaunt, H.E., Bernard, B., Hidalgo, S., Proaño, A., Wright, H., Mothes, P., Criollo, E., Kueppers, U., 2016. Juvenile magma recognition and eruptive dynamics inferred from the analysis of ash 
time series: The 2015 reawakening of Cotopaxi volcano. Journal of Volcanology and Geothermal Research 328, 134-146. https://doi.org/10.1016/j.jvolgeores.2016.10.013

Gaunt, H.E., Burgisser, A., Mothes, P.A., Browning, J., Meredith, P.G., Criollo, E., Bernard, B., 2020. Triggering of the powerful 14 July 2013 Vulcanian explosion at Tungurahua Volcano, Ecuador. Journal of Volcanology and Geothermal Research 392, 106762. https://doi.org/10.1016/j.jvolgeores.2019.106762

Giacomoni, P.P., Coltorti, M., Mollo, S., Ferlito, C., Braiato, M., Scarlato, P., 2018. The 2011-2012 paroxysmal eruptions at Mt. Etna volcano: Insights on the vertically zoned plumbing system. Journal of Volcanology and Geothermal Research 349, 370-391. https://doi.org/10.1016/j.jvolgeores.2017.11.023

Hall, M.L., Steele, A.L., Bernard, B., Mothes, P.A., Vallejo, S.X., Douillet, G.A., Ramón, P.A., Aguaiza, S.X., Ruiz, M.C., 2015. Sequential plug formation, disintegration by Vulcanian explosions, and the generation of granular Pyroclastic Density Currents at Tungurahua volcano (2013-2014), Ecuador. Journal of Volcanology and Geothermal Research 306, 90-103. https://doi.org/10.1016/j.jvolgeores.2015.09.009

Hammer, J.E., Rutherford, M.J., 2002. An experimental study of the kinetics of decompressioninduced crystallization in silicic melt. Journal of Geophysical Research: Solid Earth 107, ECV 8-1-ECV 8-24. https://doi.org/10.1029/2001JB000281

Helz et al., 2014. Helz, R.T., Clague, D.A., Sisson, T.W. and Thornber, C.R., 2014. Petrologic insights into basaltic volcanism at historically active Hawaiian volcanoes (No. 1801-6, pp. 237-292). US Geological Survey.

Honour, V.C., Holness, M.B., Charlier, B., Piazolo, S.C., Namur, O., Prosa, T.J., Martin, I., Helz, R.T., Maclennan, J., Jean, M.M., 2019. Compositional boundary layers trigger liquid unmixing in a basaltic crystal mush. Nat Commun 10, 4821. https://doi.org/10.1038/s41467-019-12694-5

Iguchi, M., Yakiwara, H., Tameguri, T., Hendrasto, M., Hirabayashi, J., 2008. Mechanism of explosive eruption revealed by geophysical observations at the Sakurajima, Suwanosejima and Semeru volcanoes. Journal of Volcanology and Geothermal Research, Dynamics of Volcanic Explosions: Field Observations, Experimental Constraints and Integrated Modelling of Volcanic Explosions: Field Observations, Experimental Constraints and Integrated Modelling 178, 1-9. https://doi.org/10.1016/j.jvolgeores.2007.10.010

Jaupart, C., Vergniolle, S., 1989. The generation and collapse of a foam layer at the roof of a basaltic magma chamber. Journal of Fluid Mechanics 203, 347-380. https://doi.org/10.1017/S0022112089001497

Johnson, J.B., Watson, L.M., Palma, J.L., Dunham, E.M., Anderson, J.F., 2018. Forecasting the Eruption of an Open-Vent Volcano Using Resonant Infrasound Tones. Geophysical Research Letters 45, 2213-2220. https://doi.org/10.1002/2017GL076506

Landi, P., Métrich, N., Bertagnini, A., Rosi, M., 2004. Dynamics of magma mixing and degassing recorded in plagioclase at Stromboli (Aeolian Archipelago, Italy). Contrib Mineral Petrol 147, 213-227. https://doi.org/10.1007/s00410-004-0555-5

Lindoo, A., Larsen, J.F., Cashman, K.V., Oppenheimer, J., 2017. Crystal controls on permeability development and degassing in basaltic andesite magma. Geology 45, 831-834. https://doi.org/10.1130/G39157.1

Liu, E.J., Cashman, K.V., Rust, A.C., 2015. Optimising shape analysis to quantify volcanic ash morphology. GeoResJ 8, 14-30. https://doi.org/10.1016/j.grj.2015.09.001

Lloyd, A.S., Ruprecht, P., Hauri, E.H., Rose, W., Gonnermann, H.M., Plank, T., 2014. NanoSIMS results from olivine-hosted melt embayments: Magma ascent rate during explosive basaltic eruptions. Journal of Volcanology and Geothermal Research 283, 1-18. https://doi.org/10.1016/j.jvolgeores.2014.06.002

Lyons, J.J., Waite, G.P., Rose, W.I., Chigna, G., 2010. Patterns in open vent, strombolian behavior at Fuego volcano, Guatemala, 2005-2007. Bull Volcanol 72, 1-15. https://doi.org/10.1007/s00445-009-0305-7 
Matzen, A.K., Baker, M.B., Beckett, J.R., Stolper, E.M., 2011. Fe-Mg Partitioning between Olivine and High-magnesian Melts and the Nature of Hawaiian Parental Liquids. J Petrology 52, 12431263. https://doi.org/10.1093/petrology/egq089

McCormick Kilbride, B., Edmonds, M., Biggs, J., 2016. Observing eruptions of gas-rich compressible magmas from space. Nature Communications 7, 1-8. https://doi.org/10.1038/ncomms13744

Métrich, N., Bertagnini, A., Di Muro, A., 2010. Conditions of Magma Storage, Degassing and Ascent at Stromboli: New Insights into the Volcano Plumbing System with Inferences on the Eruptive Dynamics. J Petrology 51, 603-626. https://doi.org/10.1093/petrology/egp083

Métrich, N., Bertagnini, A., Landi, P., Rosi, M., Belhadj, O., 2005. Triggering mechanism at the origin of paroxysms at Stromboli (Aeolian Archipelago, Italy): The 5 April 2003 eruption. Geophysical Research Letters 32. https://doi.org/10.1029/2004GL022257

Miwa, T., Geshi, N., Shinohara, H., 2013. Temporal variation in volcanic ash texture during a vulcanian eruption at the Sakurajima volcano, Japan. Journal of Volcanology and Geothermal Research 260, 80-89. https://doi.org/10.1016/j.jvolgeores.2013.05.010

Miwa, T., Toramaru, A., 2013. Conduit process in vulcanian eruptions at Sakurajima volcano, Japan: Inference from comparison of volcanic ash with pressure wave and seismic data. Bull Volcanol 75, 685. https://doi.org/10.1007/s00445-012-0685-y

Moore, L.R., Gazel, E., Tuohy, R., Lloyd, A.S., Esposito, R., Steele-Maclnnis, M., Hauri, E.H., Wallace, P.J., Plank, T., Bodnar, R.J., 2015. Bubbles matter: An assessment of the contribution of vapor bubbles to melt inclusion volatile budgets. American Mineralogist 100, 806-823. https://doi.org/10.2138/am-2015-5036

Nadeau, P.A., Palma, J.L., Waite, G.P., 2011. Linking volcanic tremor, degassing, and eruption dynamics via SO2 imaging. Geophys. Res. Lett. 38, n/a-n/a. https://doi.org/10.1029/2010GL045820

Naismith, A.K., Matthew Watson, I., Escobar-Wolf, R., Chigna, G., Thomas, H., Coppola, D., Chun, C., 2019. Eruption frequency patterns through time for the current (1999-2018) activity cycle at Volcán de Fuego derived from remote sensing data: Evidence for an accelerating cycle of explosive paroxysms and potential implications of eruptive activity. Journal of Volcanology and Geothermal Research 371, 206-219. https://doi.org/10.1016/j.jvolgeores.2019.01.001

Oppenheimer, J., Capponi, A., Cashman, K.V., Lane, S.J., Rust, A.C., James, M.R., 2020. Analogue experiments on the rise of large bubbles through a solids-rich suspension: A "weak plug" model for Strombolian eruptions. Earth and Planetary Science Letters 531, 115931. https://doi.org/10.1016/j.epsl.2019.115931

Oppenheimer, J., Rust, A.C., Cashman, K.V., Sandnes, B., 2015. Gas migration regimes and outgassing in particle-rich suspensions. Front. Phys. 3. https://doi.org/10.3389/fphy.2015.00060

Palma, J.L., Calder, E.S., Basualto, D., Blake, S., Rothery, D.A., 2008. Correlations between SO2 flux, seismicity, and outgassing activity at the open vent of Villarrica volcano, Chile. Journal of Geophysical Research: Solid Earth 113. https://doi.org/10.1029/2008JB005577

Pardini, F., Queißer, M., Naismith, A., Watson, I.M., Clarisse, L., Burton, M.R., 2019. Initial constraints on triggering mechanisms of the eruption of Fuego volcano (Guatemala) from 3 June 2018 using IASI satellite data. Journal of Volcanology and Geothermal Research 376, 54-61. https://doi.org/10.1016/j.jvolgeores.2019.03.014

Parfitt, E.A., Wilson, L., 1995. Explosive volcanic eruptions-IX. The transition between Hawaiianstyle lava fountaining and Strombolian explosive activity. Geophys J Int 121, 226-232. https://doi.org/10.1111/j.1365-246X.1995.tb03523.x

Parman, S.W., Grove, T.L., Kelley, K.A., Plank, T., 2011. Along-Arc Variations in the Pre-Eruptive H2O Contents of Mariana Arc Magmas Inferred from Fractionation Paths. J Petrology 52, 257278. https://doi.org/10.1093/petrology/egq079 
Pioli, L., Azzopardi, B.J., Cashman, K.V., 2009. Controls on the explosivity of scoria cone eruptions: Magma segregation at conduit junctions. Journal of Volcanology and Geothermal Research 186, 407-415. https://doi.org/10.1016/j.jvolgeores.2009.07.014

Pompilio, M., Bertagnini, A., Del Carlo, P., Di Roberto, A., 2017. Magma dynamics within a basaltic conduit revealed by textural and compositional features of erupted ash: the December 2015 Mt. Etna paroxysms. Scientific Reports 7, 1-14. https://doi.org/10.1038/s41598-017-05065-x

Ripepe, M., Donne, D.D., Genco, R., Maggio, G., Pistolesi, M., Marchetti, E., Lacanna, G., Ulivieri, G., Poggi, P., 2015. Volcano seismicity and ground deformation unveil the gravity-driven magma discharge dynamics of a volcanic eruption. Nature Communications 6, 1-6. https://doi.org/10.1038/ncomms7998

Ripepe, M., Pistolesi, M., Coppola, D., Delle Donne, D., Genco, R., Lacanna, G., Laiolo, M., Marchetti, E., Ulivieri, G., Valade, S., 2017. Forecasting Effusive Dynamics and Decompression Rates by Magmastatic Model at Open-vent Volcanoes. Scientific Reports 7, 1-9. https://doi.org/10.1038/s41598-017-03833-3

Roeder, P.L., Emslie, R.F., 1970. Olivine-liquid equilibrium. Contr. Mineral. and Petrol. 29, 275-289. https://doi.org/10.1007/BF00371276

Roggensack, K., 2001. Unraveling the 1974 eruption of Fuego volcano (Guatemala) with small crystals and their young melt inclusions 5 .

Romero, J.E., Vera, F., Polacci, M., Morgavi, D., Arzilli, F., Alam, M.A., Bustillos, J.E., Guevara, A., Johnson, J.B., Palma, J.L., Burton, M., Cuenca, E., Keller, W., 2018. Tephra From the 3 March 2015 Sustained Column Related to Explosive Lava Fountain Activity at Volcán Villarrica (Chile). Front. Earth Sci. 6. https://doi.org/10.3389/feart.2018.00098

Rose, W.I., Anderson, A.T., Woodruff, L.G., Bonis, S.B., 1978. The October 1974 basaltic tephra from Fuego volcano: Description and history of the magma body. Journal of Volcanology and Geothermal Research 4, 3-53. https://doi.org/10.1016/0377-0273(78)90027-6

Rose, W.I., Self, S., Murrow, P.J., Bonadonna, C., Durant, A.J., Ernst, G.G.J., 2008. Nature and significance of small volume fall deposits at composite volcanoes: Insights from the October 14, 1974 Fuego eruption, Guatemala. Bull Volcanol 70, 1043-1067. https://doi.org/10.1007/s00445-007-0187-5

Samaniego, P., Le Pennec, J.-L., Robin, C., Hidalgo, S., 2011. Petrological analysis of the pre-eruptive magmatic process prior to the 2006 explosive eruptions at Tungurahua volcano (Ecuador). Journal of Volcanology and Geothermal Research 199, 69-84. https://doi.org/10.1016/j.jvolgeores.2010.10.010

Saunders, K., Blundy, J., Dohmen, R., Cashman, K., 2012. Linking Petrology and Seismology at an Active Volcano. Science 336, 1023-1027. https://doi.org/10.1126/science.1220066

Sparks, S.R.J., Sigurdsson, H., Wilson, L., 1977. Magma mixing: a mechanism for triggering acid explosive eruptions. Nature 267, 315-318. https://doi.org/10.1038/267315a0

Spilliaert, N., Allard, P., Métrich, N., Sobolev, A.V., 2006. Melt inclusion record of the conditions of ascent, degassing, and extrusion of volatile-rich alkali basalt during the powerful 2002 flank eruption of Mount Etna (Italy). Journal of Geophysical Research: Solid Earth 111. https://doi.org/10.1029/2005JB003934

Stevenson, J.A., Millington, S.C., Beckett, F.M., Swindles, G.T., Thordarson, T., 2015. Big grains go far: Understanding the discrepancy between tephrochronology and satellite infrared measurements of volcanic ash. Atmospheric Measurement Techniques 8, 2069-2091.

Suckale, J., Keller, T., Cashman, K.V., Persson, P.-O., 2016. Flow-to-fracture transition in a volcanic mush plug may govern normal eruptions at Stromboli. Geophysical Research Letters 43, 12,071-12,081. https://doi.org/10.1002/2016GL071501

Taddeucci, J., Pompilio, M., Scarlato, P., 2002. Monitoring the explosive activity of the July-August 2001 eruption of Mt. Etna (Italy) by ash characterization. Geophysical Research Letters 29, 71-1-71-4. https://doi.org/10.1029/2001GL014372 
Thornber et al., 2015. Thornber, C.R., Orr, T.R., Heliker, C. and Hoblitt, R.P., 2015. Petrologic testament to changes in shallow magma storage and transport during 30+ years of recharge and eruption at Kïlauea Volcano, Hawai 'i. Hawaiian Volcanoes: From Source to Surface, 208, p.147.

Vergniolle, S., Jaupart, C., 1986. Separated two-phase flow and basaltic eruptions. Journal of Geophysical Research: Solid Earth 91, 12842-12860. https://doi.org/10.1029/JB091iB12p12842

Viccaro, M., Calcagno, R., Garozzo, I., Giuffrida, M., Nicotra, E., 2015. Continuous magma recharge at Mt. Etna during the 2011-2013 period controls the style of volcanic activity and compositions of erupted lavas. Miner Petrol 109, 67-83. https://doi.org/10.1007/s00710014-0352-4

Viccaro, M., Garozzo, I., Cannata, A., Di Grazia, G., Gresta, S., 2014. Gas burst vs. gas-rich magma recharge: A multidisciplinary study to reveal factors controlling triggering of the recent paroxysmal eruptions at Mt. Etna. Journal of Volcanology and Geothermal Research 278279, 1-13. https://doi.org/10.1016/j.jvolgeores.2014.04.001

Viccaro, M., Giacomoni, P.P., Ferlito, C., Cristofolini, R., 2010. Dynamics of magma supply at Mt. Etna volcano (Southern Italy) as revealed by textural and compositional features of plagioclase phenocrysts. Lithos 116, 77-91. https://doi.org/10.1016/j.lithos.2009.12.012

Viccaro, M., Giuffrida, M., Zuccarello, F., Scandura, M., Palano, M., Gresta, S., 2019. Violent paroxysmal activity drives self-feeding magma replenishment at Mt. Etna. Scientific Reports 9, 1-14. https://doi.org/10.1038/s41598-019-43211-9

Waite, G.P., Nadeau, P.A., Lyons, J.J., 2013. Variability in eruption style and associated very long period events at Fuego volcano, Guatemala: VLP EVENTS AND ERUPTION VARIABILITY. J. Geophys. Res. Solid Earth 118, 1526-1533. https://doi.org/10.1002/jgrb.50075

Wallace, K., Snedigar, S., Cameron, C., 2015. 'Is Ash Falling?', an online ashfall reporting tool in support of improved ashfall warnings and investigations of ashfall processes. J Appl. Volcanol. 4, 8. https://doi.org/10.1186/s13617-014-0022-6

Wallace, K.L., Neal, C.A., McGimsey, R.G., 2010. Timing, distribution, and character of tephra fall from the 2005-2006 eruption of Augustine Volcano: Chaper 9 in The 2006 eruption of Augustine Volcano (USGS Numbered Series No. 1769-9), Timing, distribution, and character of tephra fall from the 2005-2006 eruption of Augustine Volcano: Chaper 9 in The 2006 eruption of Augustine Volcano, Professional Paper. U.S. Geological Survey. https://doi.org/10.3133/pp17699

Wallace, K.L., Schaefer, J.R., Coombs, M.L., 2013. Character, mass, distribution, and origin of tephrafall deposits from the 2009 eruption of Redoubt Volcano, Alaska-Highlighting the significance of particle aggregation. Journal of Volcanology and Geothermal Research, The 2009 Eruption of Redoubt Volcano, Alaska 259, 145-169. https://doi.org/10.1016/j.jvolgeores.2012.09.015

Ward, 1963. Ward JHJR . Hierachical groupings to optimize an objective function. J Am Stat Assoc 1963; 58:234-44.

Williamson, B.J., Di Muro, A., Horwell, C.J., Spieler, O., Llewellin, E.W., 2010. Injection of vesicular magma into an andesitic dome at the effusive-explosive transition. Earth and Planetary Science Letters 295, 83-90. https://doi.org/10.1016/j.epsl.2010.03.027

World Bank, 2019. Concatenated Volcanic Hazards Fuego Volcano Crisis (No. AUS0000889). World Bank Group, Washington, D. C.

Wright, H.M.N., Cashman, K.V., Mothes, P.A., Hall, M.L., Ruiz, A.G., Pennec, J.-L.L., 2012. Estimating rates of decompression from textures of erupted ash particles produced by 1999-2006 eruptions of Tungurahua volcano, Ecuador. Geology 40, 619-622. https://doi.org/10.1130/G32948.1 
Wright, H.M.N., Cashman, K.V., Rosi, M., Cioni, R., 2007. Breadcrust bombs as indicators of Vulcanian eruption dynamics at Guagua Pichincha volcano, Ecuador. Bull Volcanol 69, 281-300.

1028 https://doi.org/10.1007/s00445-006-0073-6 